\title{
Electronic and lonic Transport in Ce0.8PrxTb0.2xO2 and Evaluation of Performance as Oxygen Permeation Membranes
}

\author{
Chatzichristodoulou, Christodoulos; Hendriksen, Peter Vang
}

Published in:

Journal of The Electrochemical Society

Link to article, DOI:

10.1149/2.017211jes

Publication date:

2012

Document Version

Publisher's PDF, also known as Version of record

Link back to DTU Orbit

Citation (APA):

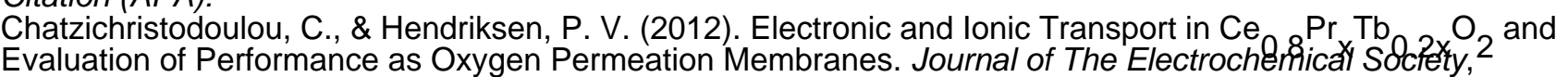
159(11), E162-E170. https://doi.org/10.1149/2.017211jes

\section{General rights}

Copyright and moral rights for the publications made accessible in the public portal are retained by the authors and/or other copyright owners and it is a condition of accessing publications that users recognise and abide by the legal requirements associated with these rights.

- Users may download and print one copy of any publication from the public portal for the purpose of private study or research.

- You may not further distribute the material or use it for any profit-making activity or commercial gain

- You may freely distribute the URL identifying the publication in the public portal 


\title{
Electronic and Ionic Transport in $\mathrm{Ce}_{0.8} \operatorname{Pr}_{\mathrm{x}} \mathrm{Tb}_{0.2-\mathrm{x}} \mathrm{O}_{2-\delta}$ and Evaluation of Performance as Oxygen Permeation Membranes
}

\author{
C. Chatzichristodoulou ${ }^{\mathrm{z}}$ and P. V. Hendriksen
}

\author{
Department of Energy Conversion and Storage, Technical University of Denmark, DK-4000 Roskilde, Denmark
}

\begin{abstract}
The electronic conductivity of $\mathrm{Ce}_{0.8} \mathrm{Pr}_{\mathrm{x}} \mathrm{Tb}_{0.2-\mathrm{x}} \mathrm{O}_{2-\delta}(\mathrm{x}=0,0.05,0.10,0.15,0.20)$ was determined in the oxygen activity range $\mathrm{a}_{\mathrm{O} 2}$ $\approx 10^{3}-10^{-17}$ at $700-900^{\circ} \mathrm{C}$ by Hebb-Wagner polarization. The electronic conductivity of all the $\mathrm{Ce}_{0.8} \operatorname{Pr}_{\mathrm{x}} \mathrm{Tb}_{0.2-\mathrm{x}} \mathrm{O}_{2-\delta}$ compositions was significantly enhanced as compared to that of $\mathrm{Ce}_{0.9} \mathrm{Gd}_{0.1} \mathrm{O}_{1.95-\delta}$, and was found to increase with increasing $\mathrm{Pr} / \mathrm{Tb}$ ratio. $\mathrm{The}$ oxide ion mobility in $\mathrm{Ce}_{0.8} \mathrm{Pr}_{\mathrm{x}} \mathrm{Tb}_{0.2-\mathrm{x}} \mathrm{O}_{2-\delta}$ is similar to that in $\mathrm{Ce}_{1-2 \delta} \mathrm{Gd}_{2 \delta} \mathrm{O}_{2-\delta}$ at the same oxygen vacancy concentration. Based on the measured ionic and electronic conductivities, fluxes through thin film $\mathrm{Ce}_{0.8} \mathrm{Pr}_{\mathrm{x}} \mathrm{Tb}_{0.2-\mathrm{x}} \mathrm{O}_{2-\delta}$ membranes were calculated.

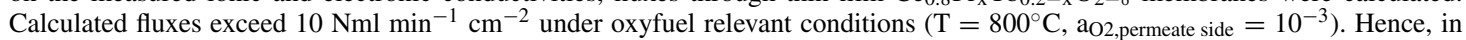
terms of transport properties, these materials are promising for this application. Interference between the ionic and electronic flows has a significant positive effect on the deliverable oxygen flux, as evaluated for $\mathrm{Ce}_{0.8} \operatorname{Pr}_{0.2} \mathrm{O}_{2-\delta}{ }^{1}$ (C) 2012 The Electrochemical Society. [DOI: 10.1149/2.017211jes] All rights reserved.
\end{abstract}

Manuscript submitted June 12, 2012; revised manuscript received July 30, 2012. Published August 31, 2012. This was Paper 402 presented at the Seattle, Washington, Meeting of the Society, May 6-10, 2012.

Materials with mixed oxide-ionic and electronic conductivity play an important role in various high temperature electrochemical devices, such as solid oxide fuel cells (SOFC), solid oxide electrolysis cells (SOEC) and oxygen permeation membranes (OPM). Among the class of mixed conductors, doped-ceria systems have been extensively studied, as they show high oxide-ionic conductivity when acceptor doped and mixed conductivity under appropriate doping or at sufficiently low oxygen activity, while at the same time they are chemically stable under conditions of very low oxygen activities ${ }^{2}$ and in $\mathrm{CO}_{2}$ containing atmospheres.

The ionic conductivity of acceptor-doped ceria has been found to depend strongly on the dopant type and concentration, ${ }^{3-5}$ showing a maximum at an oxygen vacancy concentration of $\sim 3 \%$ $\left(\mathrm{Ce}_{1-\mathrm{y}} \mathrm{M}_{\mathrm{y}} \mathrm{O}_{1.94}\right)$. The observed dependence has been extensively discussed in the literature on the basis of association between oxygen vacancies and dopants, and the concept of a critical radius of the dopant ion that optimizes the conductivity by minimizing the lattice distortion has been introduced. ${ }^{3-8}$

Molecular dynamics simulations s,10 $^{9}$ and quantum-mechanical first-principles calculations ${ }^{11}$ have further elucidated the importance of the dopant ionic radius, concluding that optimal conductivity should be expected when the attractive coulombic interaction between lowervalent dopants and oxygen vacancies is counterbalanced by a repulsive elastic strain interaction due to dopant-host mismatch. ${ }^{11}$ Butler et al. ${ }^{9}$ and Minervini et al. ${ }^{10}$ suggested $\mathrm{Gd}$ as being the ideal dopant, in terms of enhancing the ionic conductivity of ceria, whereas Andersson et al. ${ }^{11}$ concluded that the optimum dopant should have an effective atomic number between $61(\mathrm{Pm})$ and $62(\mathrm{Sm})$. They further concluded that co-doping with $\mathrm{Nd} / \mathrm{Sm}$ or $\mathrm{Pr} / \mathrm{Gd}$ should result in enhanced ionic conductivity, as compared to that obtained by doping with any of these elements separately. ${ }^{11}$

Experimental investigations suggest $\mathrm{Gd}, \mathrm{Sm}$ or $\mathrm{Y}$ as being the optimum dopant for enhanced ionic conductivity. ${ }^{6,12,13}$ Large scatter is however observed, ${ }^{14}$ not allowing for a definite conclusion. This is usually attributed to microstructural differences and impurity level variations. ${ }^{12}$ In a recent study, covering a large number of 10 at.\% rare earth doped cerias, synthesized under similar conditions, $\mathrm{Nd}$ doping was found to yield the highest ionic conductivity. ${ }^{14}$ A Nd/Sm codoped composition $\mathrm{Ce}_{0.9} \mathrm{Sm}_{0.05} \mathrm{Nd}_{0.05} \mathrm{O}_{2-\delta}$ was also investigated but found to have a similar ionic conductivity as $\mathrm{Ce}_{0.9} \mathrm{Nd}_{0.1} \mathrm{O}_{2-\delta}$ within experimental uncertainty. ${ }^{14}$ Enhanced ionic conductivity has been observed in the past though for co-doped cerates, as compared to the end members. ${ }^{15-18}$

Partial reduction of $\mathrm{Ce}^{4+}$ to $\mathrm{Ce}^{3+}$ that takes place with decreasing oxygen partial pressure and increasing temperature, introduces electronic conductivity via a small polaron hopping mechanism. ${ }^{19}$ The

${ }^{\text {z} E-m a i l: ~ c c h a @ r i s o e . d t u . d k ~}$ electronic conductivity may be detrimental for the use of ceria as an SOFC electrolyte at high temperatures, ${ }^{20}$ but makes it a promising material for oxygen permeation membranes. Oxygen fluxes in excess of

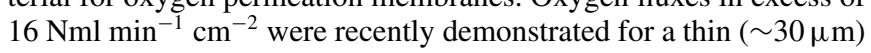
$\mathrm{Ce}_{0.9} \mathrm{Gd}_{0.1} \mathrm{O}_{1.95-\delta}(\mathrm{CGO} 10)$ membrane operating at $1175 \mathrm{~K}$ with air at the feed side and $\mathrm{H}_{2} / \mathrm{H}_{2} \mathrm{O}=20$ at the permeate side. ${ }^{21}$ The electronic conductivity of CGO10 under the operating conditions was found to be the limiting factor for oxygen permeation. ${ }^{21}$ Doping with Pr or Tb has been shown to increase the electronic conductivity of ceria at relatively high oxygen partial pressures ${ }^{1,22-35}$ and is therefore expected to improve oxygen permeation.

We have in the past reported on the defect chemistry ${ }^{36-38}$ and thermomechanical properties ${ }^{38}$ of $\mathrm{Ce}_{0.8} \mathrm{Pr}_{\mathrm{x}} \mathrm{Tb}_{0.2-\mathrm{x}} \mathrm{O}_{2-\delta}$. All the Onsager coefficients of transport for $\mathrm{Ce}_{0.8} \mathrm{Pr}_{0.2} \mathrm{O}_{2-\delta}$, including the cross terms, were measured within the a $\mathrm{O}_{2}$ range $10^{-21}-1$ at $800^{\circ} \mathrm{C}$, using local ionic and electronic probes and small applied signals in a four probe configuration. ${ }^{1}$ The cross coefficients of transport were found to be of the same order of magnitude as the direct coefficients for high $\mathrm{a}_{\mathrm{O} 2}$ values $\left(10^{-2}-1\right)$, in contrast to the commonly used assumption that the two types of carriers migrate independently. This phenomenon is commonly known as ionic interference effect, and reflects the dependence of the migration of one charge carrier to the migration of a different charge carrier in a mixed conductor. ${ }^{39}$ Furthermore, $\mathrm{Ce}_{0.8} \mathrm{Pr}_{0.2} \mathrm{O}_{2-\delta}$ was used as an example to discuss the case of Hebb-Wagner polarization in the presence of redox-active dopants and non-negligible ionic interference effect. ${ }^{40}$ The electronic conductivity of $\mathrm{Ce}_{0.8} \operatorname{Pr}_{0.2} \mathrm{O}_{2-\delta}$ under suppressed ionic flow was thus determined as a function of the oxygen activity in the range from $\mathrm{a}_{\mathrm{O} 2} \approx 10^{3}$ to $\mathrm{a}_{\mathrm{O} 2} \approx 10^{-17}$ for temperatures between $700^{\circ} \mathrm{C}$ and $900^{\circ} \mathrm{C}$.

Here the ionic and electronic transport properties of $\mathrm{Ce}_{0.8} \mathrm{Pr}_{\mathrm{x}} \mathrm{Tb}_{0.2-\mathrm{x}} \mathrm{O}_{2-\delta}(\mathrm{x}=0,0.05,0.10,0.15,0.20)$ are reported. Based on the estimated transport properties, the expected oxygen permeation flux, under conditions relevant for syngas or oxyfuel applications, is calculated by modeling and compared to that of $\mathrm{Ce}_{0.9} \mathrm{Gd}_{0.1} \mathrm{O}_{1.95-\delta}$. The importance of the ionic interference effect on the estimated oxygen permeation flux, and the error associated with assuming negligible ionic interference, is also discussed for the case of $\mathrm{Ce}_{0.8} \mathrm{Pr}_{0.2} \mathrm{O}_{2-\delta}$.

\section{Experimental}

Sample preparation.- Powders of $\mathrm{Ce}_{0.8} \mathrm{Pr}_{\mathrm{x}} \mathrm{Tb}_{0.2-\mathrm{x}} \mathrm{O}_{2-\delta}$ were synthesized by co-precipitation. ${ }^{37}$ Disk shaped samples and rods were prepared at a uniaxial pressure of $\sim 3 \mathrm{MPa}$ and further isostatic pressure of $325 \mathrm{MPa}$. The specimens were sintered at $1500^{\circ} \mathrm{C}$ in air for 12 hours and slowly cooled to room temperature at a rate of $0.5 \mathrm{~K} / \mathrm{min}$. Phase analysis was performed by room temperature XRD, after sintering at $1500^{\circ} \mathrm{C}$ in air, using a Bruker D8 Advance diffractometer with $\mathrm{Cu} \mathrm{K} \mathrm{K}_{\alpha}$ radiation and a PSD LynxEye detector. All compositions were 


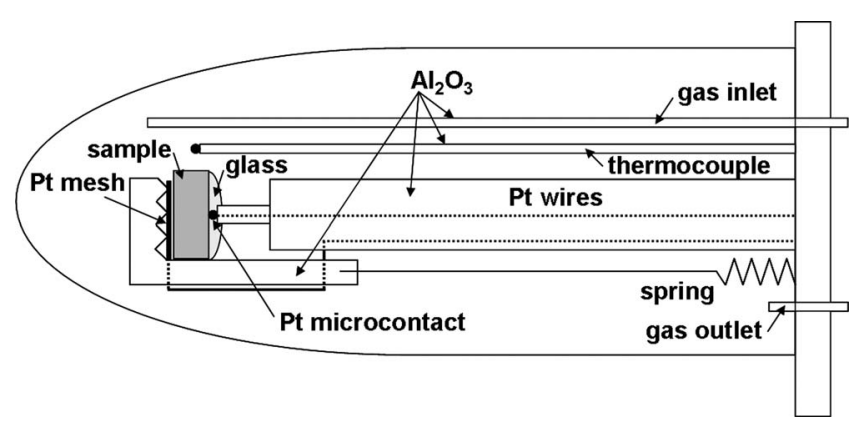

Figure 1. Experimental setup employed for the Hebb-Wagner polarization measurements.

found to be single phase fluorites. The materials compositions after synthesis were verified by Energy Dispersive X-ray Spectroscopy. The diameters of the sintered disks were $\mathrm{d} \approx 8-10 \mathrm{~mm}$ and their thickness $\mathrm{L} \approx 2 \mathrm{~mm}$. The relative densities were $\sim 95 \%$ of the theoretical value. The theoretical densities of $\mathrm{Ce}_{0.8} \operatorname{Pr}_{\mathrm{x}} \mathrm{Tb}_{0.2-\mathrm{x}} \mathrm{O}_{2-\delta}$ in air were estimated by Rietveld refinement of the X-ray diffraction patterns recorded at room temperature. ${ }^{38} \mathrm{~A}$ grain size in the range 1 $-5 \mu \mathrm{m}$ was determined by scanning electron microscopy (FE-SEM Zeiss Supra 35).

Hebb-Wagner polarization.- The sintered pellets were polished with $\mathrm{SiC}$ paper of decreasing roughness and diamond paste (down to $1 \mu \mathrm{m}$ particle size). A similar experimental setup to that proposed by Lübke and Wiemhöfer ${ }^{27}$ was used (Fig. 1). A Pt microelectrode (working electrode), with a contact radius $r \sim 100-200 \mu \mathrm{m}$ was spring loaded against the disk shaped sample. The contact radius of the $\mathrm{Pt}$ microelectrode was determined by scanning electron microscopy (FESEM Zeiss Supra 35). After contacting, the remaining surface area around the tip was covered with glass $(\mathrm{MgO} /$ sodium aluminosilicate glass composite, $30 / 70 \mathrm{vol} . \%$ ) in order to block the oxygen exchange with the gaseous atmosphere surrounding the cell. The reference electrode was prepared by covering the entire surface of the pellet, opposite the microelectrode, with Pt paste.

The electrochemical cell was then placed in a controlled atmosphere, shielded furnace. The activity of oxygen at the reference/reversible electrode was defined by flowing air around the cell. Measurements were performed in the temperature range between $700^{\circ} \mathrm{C}$ and $900^{\circ} \mathrm{C}$. The applied voltage ranged between $+200 \mathrm{mV}$ and $-800 \mathrm{mV}$, relative to the reference electrode. The voltage was applied stepwise, in steps of $25 \mathrm{mV}$ and the transient of the current toward steady state was recorded over a period of $12 \mathrm{~min}$. This duration was selected so as to be $\sim 150$ times the time constant for the relaxation, which was estimated from the relation $\tau=\mathrm{r}^{2} / 2 \mathrm{D}_{\text {chem }}$ to be $\tau \sim 5 \mathrm{~s}$, using a value of $D_{\text {chem }} \sim 1 \cdot 10^{-5} \mathrm{~cm}^{2} / \mathrm{s}$ for the chemical diffusion coefficient. ${ }^{1,41}$ A Solartron 1287 electrochemical interface was employed for the measurements. The results of the Hebb-Wagner polarization experiments were successfully reproduced using two sample replicates for each composition.

Total conductivity. - Total conductivity measurements were performed on rectangular bars $\left(\sim 2.4 \times 0.65 \times 0.15 \mathrm{~cm}^{3}\right)$ using the fourprobe dc technique in a controlled atmosphere furnace. The influence of thermovoltages was overcome by reversing the current direction. The samples were electrically contacted with platinum wires and platinum paste, and were fired at $1000^{\circ} \mathrm{C}$ for $1 \mathrm{~h}$ prior to the conductivity measurements to ensure good contact. The oxygen activity of the sample environment was controlled by flowing gas mixtures of air $/ \mathrm{N}_{2}$ or $\mathrm{N}_{2} / \mathrm{CO}_{2} / \mathrm{H}_{2}$ and monitored by a YSZ-sensor connected downstream and kept at the same temperature as the specimens used for the conductivity measurements. The samples were allowed to equilibrate for $\sim 10 \mathrm{~h}$ in each gas mixture, a duration $\sim 120$ times larger than the time constant for the relaxation, which in this case is $\tau \sim 5 \mathrm{~min}$, using again a value of $D_{\text {chem }} \sim 1 \cdot 10^{-5} \mathrm{~cm}^{2} / \mathrm{s}$ for the chemical diffusion coefficient. ${ }^{1,41}$

\section{Theoretical considerations}

Let us consider a mixed oxide-ionic and electronic conductor, where the cations are practically immobile. The charge carriers are oxygen vacancies $\left(V_{O}{ }^{\bullet \bullet}\right)$, with a formal charge of +2 , electrons $\left(e^{\prime}\right)$ and holes $\left(h^{\bullet}\right)$, with a formal charge of -1 and +1 respectively. Using the subscripts $i, e$ and $h$ for $V_{O} \bullet \bullet, e^{\prime}$ and $h^{\bullet}$ respectively, their current densities, $i_{k}(k=i, e, h)$, relative to the cation sublattice (Hittorf frame of reference), may be written as:

$$
i_{k}=-\frac{\sigma_{k}}{z_{k} F} \nabla \eta_{k}
$$

where $\sigma_{k}=\left|z_{k}\right| F c_{k} u_{k}$ is the partial conductivity, $z_{k}$ the formal charge, $c_{k}$ the concentration, $u_{k}$ the mobility and $\eta_{k}=\mu_{k}+z_{k} F \varphi$ the electrochemical potential of species $k$.

At the steady state of an ion-blocking Hebb-Wagner polarization cell, the condition $\nabla \eta_{i}=0$ is fulfilled, assuming that the ionic current is successfully blocked and interference effects between electronic and ionic charge carriers are negligible. This condition, combined with the condition of local ionization equilibrium $\left(\frac{1}{2} O_{2}(g)+V_{O}^{\bullet \bullet}+2 e^{\prime} \leftrightarrow O_{O}^{x}\right)$ allows the estimation of the oxygen activity at the blocking electrode, from the value of the oxygen activity imposed at the reference electrode, $\mathrm{a}_{\mathrm{O}_{2}, \text { ref }}$, and the potential $\mathrm{V}$ applied at the blocking electrode relative to the reference electrode:

$$
\mathrm{a}_{O_{2}, b}=\mathrm{a}_{O_{2}, r e f} \exp \left(\frac{4 F V}{R T}\right)
$$

Based on the $\mathrm{a}_{\mathrm{O} 2}$ dependency of the oxygen nonstoichiometry of $\mathrm{Ce}_{0.8} \mathrm{Pr}_{\mathrm{x}} \mathrm{Tb}_{0.2-\mathrm{x}} \mathrm{O}_{2-\delta},{ }^{37}$ it is expected that during the largest part of the I-V curve the condition $\nabla \mu_{i} \approx 0$ is valid for part of the material, the rest complying to the condition $\nabla \mu_{i} \neq 0$. When the established oxygen activity range in a Hebb-Wagner polarization experiment covers several defect regimes, a single Hebb-Wagner type equation, ${ }^{42,43}$ of the form:

$$
\begin{aligned}
I= & 4 r \frac{R T}{a F}\left[\sigma_{h, r e f}\left(\exp \left(\frac{a F V}{R T}\right)-1\right)\right. \\
& \left.+\sigma_{e, r e f}\left(1-\exp \left(-\frac{a F V}{R T}\right)\right)\right]
\end{aligned}
$$

is not able to provide an adequate description of the steady state I-V curve. In order to reproduce the steady state I-V curve in such cases, the varying $\mathrm{a}_{\mathrm{O} 2}$ dependence of the electronic defect concentrations needs to be taken into account, along with a model for the electronic transport.

The electronic conductivity of $\mathrm{Ce}_{0.8} \mathrm{Pr}_{\mathrm{x}} \mathrm{Tb}_{0.2-\mathrm{x}} \mathrm{O}_{2-\delta}$ comprises of small polaron hopping of localized electrons in the narrow $\operatorname{Pr} / \mathrm{Tb} 4 \mathrm{f}$ and $\mathrm{Ce} 4 \mathrm{f}$ bands and the broad band semiconducting behavior of holes in the $\mathrm{O} 2 p$ valence band. Within the oxygen activity range investigated here the concentration of reduced $\mathrm{Ce}$ ions is negligible and therefore the fraction of $\mathrm{Ce}^{\mathrm{x}}$ sites where the polaron may jump is in good approximation $\mathrm{x}_{\mathrm{Ce}} \approx 1$. As shown in a previous publication, ${ }^{40}$ the steady state I-V curve under ionic blocking conditions (and assuming negligible ionic interference) can be estimated as:

$$
\begin{aligned}
I= & 4 r F\left(u_{C e 4 f} \int_{0}^{V} c_{e} d V+u_{O 2 p} \int_{0}^{V} c_{h} d V+u_{\mathrm{Pr} / \mathrm{Tb} 4 f}\right. \\
& \left.\times \int_{0}^{V} c_{\mathrm{Pr} / \mathrm{Tb}^{x}} c_{\mathrm{Pr}^{\prime} / \mathrm{Tb}^{\prime}} d V\right)
\end{aligned}
$$

where $u_{C e 4 f}$ and $u_{\mathrm{Pr} / \mathrm{Tb} 4 f}$ are the mobilities of the small polaron in the $\mathrm{Ce} 4 \mathrm{f}$ and $\mathrm{Pr} / \mathrm{Tb} 4 \mathrm{f}$ bands, respectively, and $u_{O 2 p}$ the mobility of electron holes in the $\mathrm{O} 2 \mathrm{p}$ band. In a previous publication, ${ }^{40}$ the $\mathrm{p}$-type electronic conductivity of $\mathrm{Ce}_{0.8} \mathrm{Pr}_{0.2} \mathrm{O}_{2-\delta}$ was found to be dominated by small polaron hopping at the $\operatorname{Pr} 4 \mathrm{f}$ band (when assuming negligible 
ionic interference). The contribution of electron holes in the $\mathrm{O} 2 \mathrm{p}$ band can therefore be neglected and Eq. 4 is simplified to:

$$
I=4 r F\left(u_{C e 4 f} \int_{0}^{V} c_{e} d V+u_{\operatorname{Pr} 4 f} \int_{0}^{V} c_{\mathrm{Pr}^{x}} c_{\mathrm{Pr}^{\prime}} d V\right)
$$

The non-ideality of the defect chemistry of $\mathrm{Ce}_{0.8} \operatorname{Pr}_{\mathrm{x}} \mathrm{Tb}_{0.2-\mathrm{x}} \mathrm{O}_{2-\delta}{ }^{36}$ and the fact that the approximation $c_{h} \ll c_{V} \cdot \bullet, c_{\mathrm{P} r^{\prime}}$ is not valid, do not allow for a closed form solution for the I-V curve, as is the case for $\mathrm{Fe}$-doped $\mathrm{SrTiO}_{3}{ }^{44}$ In order to estimate the current from Eq. 5, the oxygen activity range in the material is estimated for an applied voltage $\mathrm{V}$ from Eq. 2 and the concentration of charge carriers within this oxygen activity range is estimated from the defect chemistry of the materials. ${ }^{36}$ The integrals are then estimated numerically. Eq. 5 is fitted to the steady state I-V curve, treating the mobilities $u_{C e 4 f}$ and $u_{\mathrm{Pr} / \mathrm{Tb} 4 f}$ as concentration independent fitting parameters. A generalization of the I-V expression, Eq. 4, for the case of non-negligible ionic interference, was given in Ref. 40. Interference effects have not been taken into account here due to lack of knowledge of the cross terms of the Onsager matrix of transport.

Modeling the oxygen flux.- An extension of the classical Wagner approach $^{45}$ has been implemented here for the modeling of the oxygen flux, allowing for the effect of non negligible ionic interference to be taken into account, as described in Ref. 1. Linear Chang-Jaffe electrode kinetics ${ }^{46}$ were used and the electrode polarization resistances, $R_{c a t}$ and $R_{a n}$, were assumed independent of the oxygen activity. The temperature dependence of the electrode polarization resistances is described in Ref. 47. Effects of gas conversion and gas diffusion were neglected here. The oxygen flux, $j_{O_{2}}$, and the oxygen activity and oxygen nonstoichiometry profiles inside the membrane under operation were estimated as described in Ref. 47.

\section{Results and Discussion}

Electronic conductivity. - The steady state I-V curves, measured at 700,800 and $900^{\circ} \mathrm{C}$ for $\mathrm{Ce}_{0.8} \mathrm{Pr}_{0.1} \mathrm{~Tb}_{0.1} \mathrm{O}_{2-\delta}$ are shown in Fig. 2, along with the fit of Eq. 5 to the data. As can be seen, Eq. 5 is very successful in describing the experimental data. Similarly good fits were obtained for the remaining $\mathrm{Ce}_{0.8} \mathrm{Pr}_{\mathrm{x}} \mathrm{Tb}_{0.2-\mathrm{x}} \mathrm{O}_{2-\delta}$ compositions, yielding the electronic mobilities for small polaron hopping at the $\mathrm{Ce}$ 4f and $\mathrm{Pr} / \mathrm{Tb} 4 \mathrm{f}$ bands, $u_{C e 4 f}$ and $u_{\mathrm{P} / \mathrm{Tbr} 4 f}$, at 700,800 and $900^{\circ} \mathrm{C}$. It is pointed out that the experimental I-V curves were recorded for a cyclic stepwise variation of the applied voltage from $0 \mathrm{mV}$ to $-800 \mathrm{mV}$ to $+200 \mathrm{mV}$ and back to $0 \mathrm{mV}$. Although the entire I-V curves have been plotted in Fig. 2, it is impossible to separate the two branches as they practically coincide. This indicates that steady state was indeed achieved at each Voltage step.

A comparison between the electronic conductivity of $\mathrm{Ce}_{0.9} \mathrm{Gd}_{0.1} \mathrm{O}_{1.95-\delta}$ and $\mathrm{Ce}_{0.8} \mathrm{Pr}_{0.2} \mathrm{O}_{2-\delta}$ at 700,800 and $900^{\circ} \mathrm{C}$ as a func-

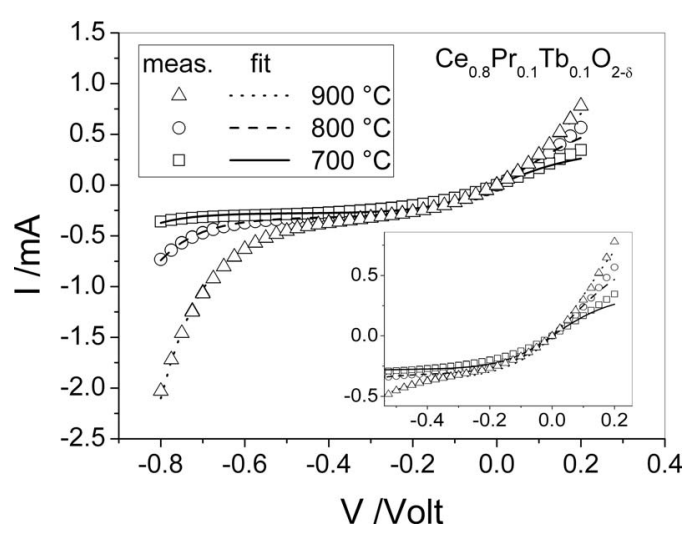

Figure 2. Steady state I-V curves of $\mathrm{Ce}_{0.8} \mathrm{Pr}_{0.1} \mathrm{~Tb}_{0.1} \mathrm{O}_{2-\delta}$ measured at 700, 800 and $900^{\circ} \mathrm{C}$, along with the fit obtained with Eq. 5 .

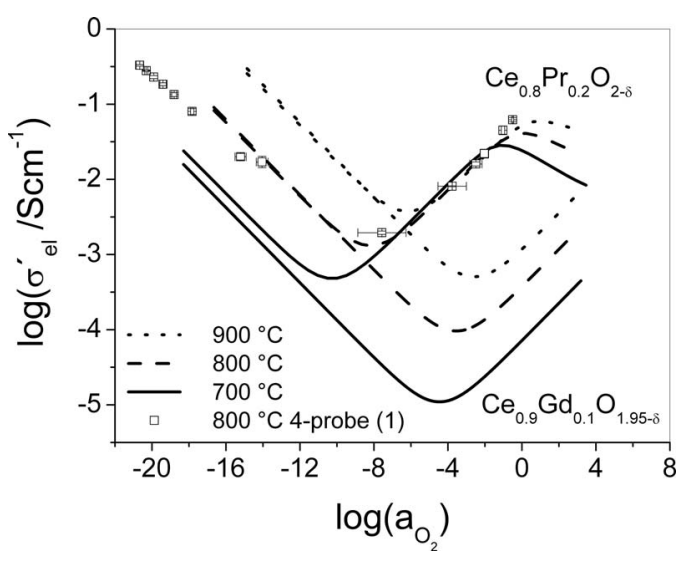

Figure 3. Electronic conductivity of $\mathrm{Ce}_{0.9} \mathrm{Gd}_{0.1} \mathrm{O}_{1.95-\delta}$ and $\mathrm{Ce}_{0.8} \mathrm{Pr}_{0.2} \mathrm{O}_{2-\delta}$ under suppressed ionic flow at 700,800 and $900^{\circ} \mathrm{C}$ as a function of the oxygen activity. The electronic conductivity of $\mathrm{Ce}_{0.8} \operatorname{Pr}_{0.2} \mathrm{O}_{2-\delta}$ measured by a 4-probe cell at $800^{\circ} \mathrm{C}^{1}$ is included as well $(\square)$.

tion of the oxygen activity ${ }^{40}$ is presented in Fig. 3. As can be seen, the electronic conductivity of $\mathrm{Ce}_{0.8} \mathrm{Pr}_{0.2} \mathrm{O}_{2-\delta}$ is significantly enhanced relative to that of $\mathrm{Ce}_{0.9} \mathrm{Gd}_{0.1} \mathrm{O}_{1.95-\delta}$ in the high $\mathrm{a}_{\mathrm{O} 2}$ range, by as much as three orders of magnitude. The n-type region is approximately the same for both compounds. In the high $\mathrm{a}_{\mathrm{O} 2}$ range the electronic conductivity of $\mathrm{Ce}_{0.8} \operatorname{Pr}_{0.2} \mathrm{O}_{2-\delta}$ passes through a maximum when $c_{\mathrm{Pr}_{C e}^{\prime}}=c_{\mathrm{Pr}_{C e}^{x}}$, due to the contribution of the small polarons in the Pr $4 \mathrm{f}$ band. The electronic conductivity of $\mathrm{Ce}_{0.8} \mathrm{Pr}_{0.2} \mathrm{O}_{2-\delta}$ appears to be practically temperature independent in the $\log \left(\mathrm{a}_{\mathrm{O} 2}\right)$ range between -1 and -6 . This is due to the fact that although the mobility of the small polarons in the $\operatorname{Pr} 4 \mathrm{f}$ band increases with increasing temperature the concentration of "effective" charge carriers $c_{\mathrm{Pr}_{C e}^{\prime}} \cdot c_{\mathrm{Pr}_{C e}^{x}}$ decreases with increasing temperature within the reported range.

A comparison of the electronic conductivity of the various $\mathrm{Ce}_{0.8} \mathrm{Pr}_{\mathrm{x}} \mathrm{Tb}_{0.2-\mathrm{x}} \mathrm{O}_{2-\delta}$ compounds, measured under suppressed ionic flow at 900,800 and $700^{\circ} \mathrm{C}$, is presented in Figs. $4 \mathrm{a}-4 \mathrm{c}$, respectively. A similar behavior is observed in all cases; the n-type region at low $\mathrm{a}_{\mathrm{O} 2}$ with a constant slope of $\sim-1 / 4$, characteristic of acceptor doped ceria in the $\Delta \mu_{i} \approx 0$ defect regime $\left(\left[V_{O}^{\bullet \bullet}\right] \approx\right.$ const $)$, is followed by a p-type region at higher $\mathrm{a}_{\mathrm{O} 2}$, due to small polaron hopping in the more than half full $\mathrm{Pr} / \mathrm{Tb} 4 \mathrm{f}$ band. At even higher oxygen activities, the electronic conductivity passes through a maximum, when the $\mathrm{Pr} / \mathrm{Tb}$ $4 \mathrm{f}$ band is half full, and becomes n-type again at even higher $\mathrm{a}_{\mathrm{O} 2}$, as the $\mathrm{Pr} / \mathrm{Tb}$ 4f band becomes less than half full.

The position of the maximum, which corresponds to $\delta=0.05$, when half of the dopants are reduced, is observed to shift toward lower $\mathrm{a}_{\mathrm{O} 2}$ with decreasing temperature due to the fact that the oxygen nonstoichiometry at a certain $\mathrm{a}_{\mathrm{O} 2}$ decreases with decreasing temperature, and therefore the condition $\delta=0.05$ is achieved at lower $\mathrm{a}_{\mathrm{O} 2}$. Furthermore, the position of the maximum at a certain temperature, shifts toward lower $\mathrm{a}_{\mathrm{O} 2}$ with increasing $\mathrm{Pr} / \mathrm{Tb}$ ratio, due to the fact that $\mathrm{Tb}$ is more easily reduced than $\mathrm{Pr}$ in the lattice of ceria. ${ }^{36}$ As can be seen from Figs. $4 \mathrm{a}-4 \mathrm{c}$, the electronic conductivity of $\mathrm{Ce}_{0.8} \mathrm{Pr}_{\mathrm{x}} \mathrm{Tb}_{0.2-\mathrm{x}} \mathrm{O}_{2-\delta}$ increases systematically with increasing $\mathrm{Pr} / \mathrm{Tb}$ ratio in the $\mathrm{a}_{\mathrm{O} 2}$ regime dominated by small polaron hopping at the $\mathrm{Pr} / \mathrm{Tb} 4 \mathrm{f}$ band. A similar trend is observed at the n-type region, related to small polaron hopping at the $\mathrm{Ce} 4 \mathrm{f}$ band, but the variation is not so pronounced. A slightly increasing $\mathrm{Ce} 4 \mathrm{f}$ contribution has been observed in the literature with increasing dopant ionic radii from $\mathrm{Y}$ to $\mathrm{La}^{48}$ in line with the trend observed here.

The activation energy and pre-exponential factor of the small polaron mobility at the $\mathrm{Pr} / \mathrm{Tb} 4 \mathrm{f}$ and $\mathrm{Ce} 4 \mathrm{f}$ bands were estimated from linear fitting of the $\ln (u T)$ versus $1 / T$ data. The values obtained for the various $\mathrm{Ce}_{0.8} \mathrm{Pr}_{\mathrm{x}} \mathrm{Tb}_{0.2-\mathrm{x}} \mathrm{O}_{2-\delta}$ compositions are shown in Table I. An activation energy of $\sim 0.5 \mathrm{eV}$ was determined for the small polaron hopping at the $\mathrm{Pr} / \mathrm{Tb} 4 \mathrm{f}$ band in all cases and a value of $\sim 0.3 \mathrm{eV}$ was obtained for the small polaron hopping at the $\mathrm{Ce} 4 \mathrm{f}$ band. These values 

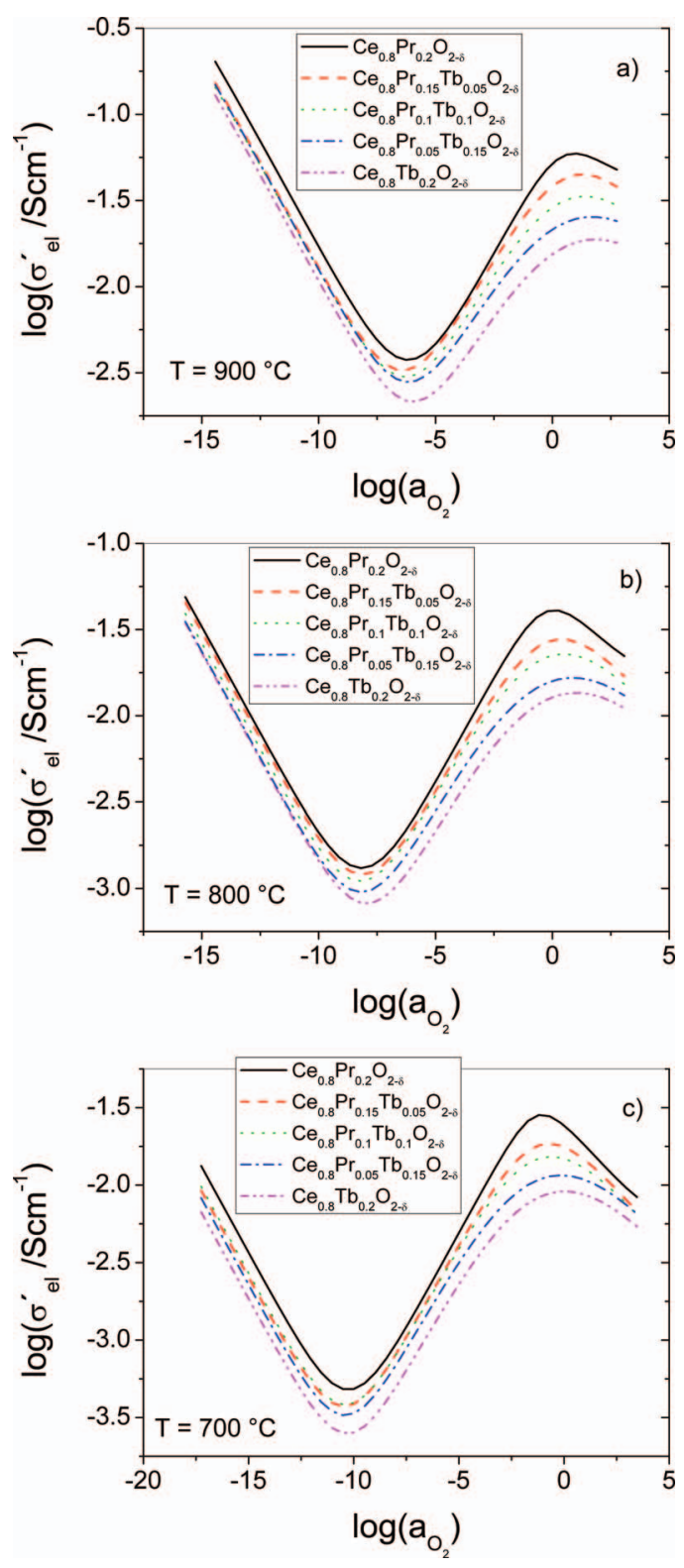

Figure 4. Electronic conductivity of $\mathrm{Ce}_{0.8} \mathrm{Pr}_{\mathrm{X}} \mathrm{Tb}_{0.2-\mathrm{x}} \mathrm{O}_{2-\delta}$ under suppressed ionic flow at a) $900^{\circ} \mathrm{C}$, b) $800^{\circ} \mathrm{C}$ and c) $700^{\circ} \mathrm{C}$.

are in good agreement with literature values for small polaron migration in other ceria systems. ${ }^{19,49,50}$ The pre-exponential factors show a decreasing tendency with decreasing $\mathrm{Pr} / \mathrm{Tb}$ ratio. The compound with $[\mathrm{Pr}]=0.15$ does not follow this trend. This is probably due to a correlation between the pre-exponential factor and the activation energy, the latter being fitted to a higher value in this case.

Table I. Activation energy and pre-exponential factor of small polaron mobility at the $\mathrm{Pr} / \mathrm{Tb} 4 \mathrm{f}$ and $\mathrm{Ce} 4 \mathrm{f}$ bands. The error estimate arises from the linear fit to the $\ln (u T)$ vs $1 / T$ data.

\begin{tabular}{ccccc}
$\begin{array}{c}{[\mathrm{Pr}]} \\
=0.20-[\mathrm{Tb}]\end{array}$ & $\begin{array}{c}u_{\mathrm{Pr} / \mathrm{Tb} 4 f}^{0} \\
\left(\mathrm{~cm}^{2} \mathrm{KV}^{-1} \mathrm{~s}^{-1}\right)\end{array}$ & $\begin{array}{c}H_{m, \operatorname{Pr} / \mathrm{Tb} 4 f} \\
(\mathrm{eV})\end{array}$ & $\begin{array}{c}u_{\text {Ce4f }}^{0} \\
\left(\mathrm{~cm}^{2} \mathrm{KV}^{-1} \mathrm{~s}^{-1}\right)\end{array}$ & $\begin{array}{c}H_{m, C e 4 f} \\
(\mathrm{eV})\end{array}$ \\
\hline 0.20 & $147 \pm 1$ & $0.45 \pm 0.01$ & $270 \pm 4$ & $0.49 \pm 0.13$ \\
0.15 & $311 \pm 2$ & $0.55 \pm 0.06$ & $88 \pm 2$ & $0.35 \pm 0.05$ \\
0.10 & $114 \pm 1$ & $0.48 \pm 0.02$ & $20 \pm 2$ & $0.25 \pm 0.05$ \\
0.05 & $55 \pm 2$ & $0.48 \pm 0.05$ & $23 \pm 3$ & $0.3 \pm 0.1$ \\
0.00 & $31 \pm 1$ & $0.45 \pm 0.01$ & $38 \pm 1$ & $0.32 \pm 0.02$
\end{tabular}

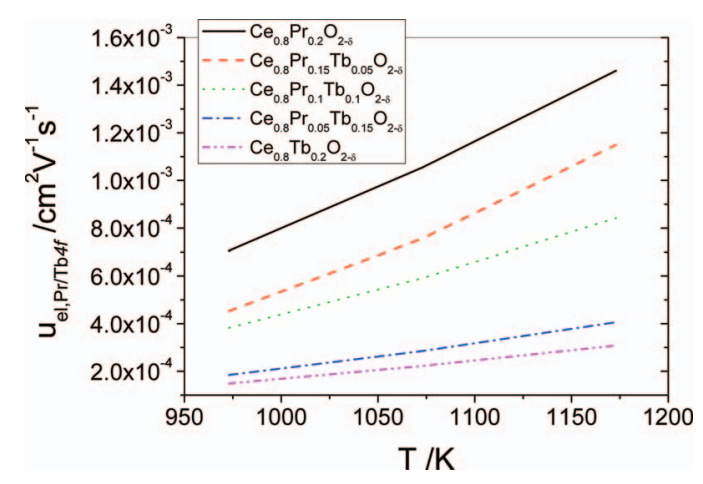

Figure 5. Electronic mobility of small polaron hopping at the $\mathrm{Pr} / \mathrm{Tb} 4 \mathrm{f}$ band of $\mathrm{Ce}_{0.8} \mathrm{Pr}_{\mathrm{x}} \mathrm{Tb}_{0.2-\mathrm{x}} \mathrm{O}_{2-\delta}$ as a function of temperature.

The temperature dependence of the electronic mobility of the small polaron at the $\operatorname{Pr} / \mathrm{Tb} 4 \mathrm{f}$ band is presented at Fig. 5 for all compositions. The electronic mobility increases with temperature in all cases, as expected for a small polaron hopping mechanism. A significant enhancement in the small polaron mobility is observed with increasing $\mathrm{Pr} / \mathrm{Tb}$ ratio. This is the reason for the enhanced electronic conductivity of the Pr rich compositions observed in Figs. $4 a-4 c$.

Total conductivity. - The total conductivity of the co-doped $\mathrm{Ce}_{0.8} \mathrm{Pr}_{\mathrm{x}} \mathrm{Tb}_{0.2-\mathrm{x}} \mathrm{O}_{2-\delta}$ compounds, measured as a function of the oxygen activity at 700,800 and $900^{\circ} \mathrm{C}$, is presented in Fig. 6. At high $\mathrm{a}_{\mathrm{O} 2}$, the total conductivity decreases with decreasing $\mathrm{a}_{\mathrm{O} 2}$. This is mainly due to the decreasing $\mathrm{Pr} / \mathrm{Tb} 4 \mathrm{f}$ small polaron contribution to the total conductivity, as discussed later. At intermediate $\mathrm{a}_{\mathrm{O} 2}$ values, the total conductivity remains approximately constant, whereas a further increase is observed with decreasing $\mathrm{a}_{\mathrm{O} 2}$ at lower oxygen activities. This is due to increasing contribution of $\mathrm{Ce} 4 \mathrm{f}$ small polarons with decreasing $\mathrm{a}_{\mathrm{O} 2}$ in this range.

Ionic conductivity. - The ionic conductivity was estimated as a function of the oxygen activity by subtracting the electronic conductivity, measured under suppressed ionic flow, from the total conductivity. An example is shown in Fig. 7 for the case of $\mathrm{Ce}_{0.8} \mathrm{Pr}_{0.1} \mathrm{~Tb}_{0.1} \mathrm{O}_{2-\delta}$ at $700^{\circ} \mathrm{C}$. The total conductivity data were interpolated with a cubic spline $\left(\sigma_{\text {tot }}\right.$ inter.), from which the electronic conductivity under suppressed ionic flow $\left(\sigma_{\mathrm{el}}^{\prime}\right)$ was subtracted. The resulting quantity, $\sigma_{\mathrm{tot}}-$ $\sigma^{\prime}{ }_{\text {el }}$, is equal to the ionic conductivity, $\sigma_{\text {ion }}$, if there is no interference between the ionic and electronic flows. ${ }^{1}$ The ionic interference effect was measured for $\mathrm{Ce}_{0.8} \mathrm{Pr}_{0.2} \mathrm{O}_{2-\delta}$ at $800^{\circ} \mathrm{C}$ as a function of the oxygen activity and was found to be negligible for $\log \mathrm{O}_{\mathrm{O} 2}<-4$, but far from zero for higher oxygen activities. ${ }^{1}$ When the ionic interference effect is not negligible, the quantity $\sigma_{\text {tot }}-\sigma_{\text {el }}^{\prime}$ provides an underestimation

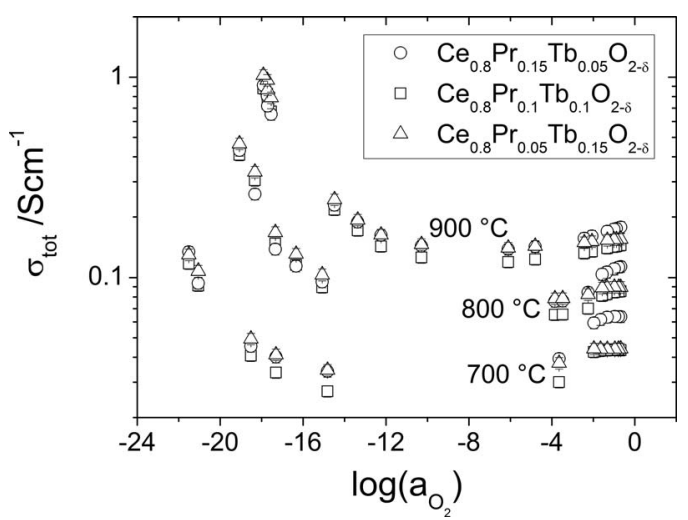

Figure 6. Total conductivity of the co-doped compositions as a function of oxygen activity at 700,800 and $900^{\circ} \mathrm{C}$. 


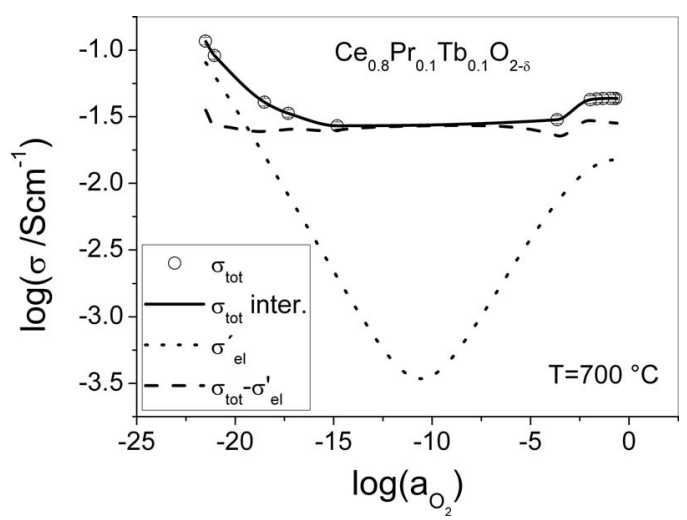

Figure 7. Separation of the total conductivity ( $\left.\sigma_{\text {tot }}\right)$ of $\mathrm{Ce}_{0.8} \operatorname{Pr}_{0.1} \mathrm{~Tb}_{0.1} \mathrm{O}_{2-\delta}$ at $700^{\circ} \mathrm{C}$ into its electronic $\left(\sigma_{\mathrm{el}}^{\prime}\right)$ and ionic $\left(\sigma_{\mathrm{tot}}-\sigma_{\mathrm{el}}^{\prime}\right)$ part as a function of oxygen activity. $\sigma_{\text {tot }}$ inter. corresponds to the interpolated total conductivity data.

of the ionic conductivity. In the case of $\mathrm{Ce}_{0.8} \mathrm{Pr}_{0.2} \mathrm{O}_{2-\delta}$ the ionic conductivity is underestimated by $\sim 35 \%$ at $\log \mathrm{O}_{\mathrm{O} 2}=-1$ at $800^{\circ} \mathrm{C}$, when assumed to be equal to $\sigma_{\text {tot }}-\sigma_{\text {el }}^{\prime}{ }^{1}$ Since the ionic interference effect is not known for the $\mathrm{Ce}_{0.8} \mathrm{Pr}_{\mathrm{x}} \mathrm{Tb}_{0.2-\mathrm{x}} \mathrm{O}_{2-\delta}$ compounds, we shall consider it negligible. It is stressed though that this assumption is most probably false for high $\mathrm{a}_{\mathrm{O} 2}$ values.

The total conductivity of $\mathrm{Ce}_{0.8} \mathrm{Pr}_{0.2} \mathrm{O}_{2-\delta}$ has been measured in the past by two groups, ${ }^{23,31,32}$ and the mean values of the partial ionic and electronic conductivities in the $\mathrm{a}_{\mathrm{O} 2}$ range between 1 and 0.21 were also determined in one case ${ }^{31,32}$ using the concentration cell technique. A comparison between the existing literature values and those estimated in this work is presented in Table II. Fagg et al. estimated a value of $0.15 \mathrm{Scm}^{-1}$ for the total conductivity of $\mathrm{Ce}_{0.8} \mathrm{Pr}_{0.2} \mathrm{O}_{2-\delta}$ at $900^{\circ} \mathrm{C}$ in air, ${ }^{31}$ whereas they found an enhancement in the total conductivity by $20 \%$ when co-doping with 2 at. $\%$ Co. ${ }^{32}$ The enhancement was attributed to increased electronic conductivity. ${ }^{32}$ Nauer et al. estimated a total conductivity of $0.17 \mathrm{Scm}^{-1}$ for $\mathrm{Ce}_{0.8} \mathrm{Pr}_{0.2} \mathrm{O}_{2-\delta}$ at $900^{\circ} \mathrm{C}$ in air, ${ }^{23}$ a value $\sim 13 \%$ larger than that measured by Fagg et al. ${ }^{31}$ In the present study, the total conductivity was estimated to be $0.2 \mathrm{Scm}^{-1}, \sim 33 \%$ larger than that measured by Fagg et al. ${ }^{31}$ Similarly large scatter has been observed in the past for other acceptor doped ceria systems, such as the well studied Gd-doped ceria. ${ }^{2,12,51,52}$ The observed scattering is believed to arise due to microstructural differences and variations in the impurity level. ${ }^{12}$ The larger total conductivity determined in the present study is both due to enhanced electronic and ionic conductivity, as can be seen from Table II.

From the ionic conductivity values, determined as a function of the oxygen activity as described previously, and the defect chemistry of the $\mathrm{Ce}_{0.8} \mathrm{Pr}_{\mathrm{x}} \mathrm{Tb}_{0.2-\mathrm{x}} \mathrm{O}_{2-\delta}$ compounds, ${ }^{37,38}$ the ionic mobility can be deduced. The ionic mobility of the $\mathrm{Ce}_{0.8} \mathrm{Pr}_{\mathrm{x}} \mathrm{Tb}_{0.2-\mathrm{x}} \mathrm{O}_{2-\delta}$ compounds, estimated at 700,800 and $900^{\circ} \mathrm{C}$, is shown in Fig. 8 as a function of the oxygen nonstoichiometry, along with that of $\mathrm{Ce}_{0.9} \mathrm{Gd}_{0.1} \mathrm{O}_{1.95}$ and $\mathrm{Ce}_{0.8} \mathrm{Gd}_{0.2} \mathrm{O}_{1.9}$ from Wang et al. ${ }^{51}$ for comparison. The ionic mobility decreases with increasing oxygen nonstoichiometry for all compositions. This is in accordance with the expected behavior of acceptor doped ceria, which arises due to increasing

Table II. Total, electronic and ionic conductivity of $\mathrm{Ce}_{0.8} \mathrm{Pr}_{0.2} \mathrm{O}_{2-\delta}$ at $900^{\circ} \mathrm{C}$ in air and comparison with literature values.

\begin{tabular}{lcccc} 
& present work & Fagg et al. $^{32 \mathrm{a}}$ & Fagg et al. ${ }^{31}$ & Nauer et al. ${ }^{23}$ \\
\hline$\sigma_{\text {tot }}\left(\mathrm{Scm}^{-1}\right)$ & 0.2 & 0.18 & 0.15 & 0.17 \\
$\sigma_{\text {el }}\left(\mathrm{Scm}^{-1}\right)$ & 0.04 & 0.055 & 0.02 & - \\
$\sigma_{\text {ion }}\left(\mathrm{Scm}^{-1}\right)$ & 0.16 & 0.125 & 0.13 & - \\
${ }^{\mathrm{a}} \mathrm{Ce}_{0.8} \mathrm{Pr}_{0.2} \mathrm{O}_{2-\delta}$ with 2 at.\% Co. & &
\end{tabular}

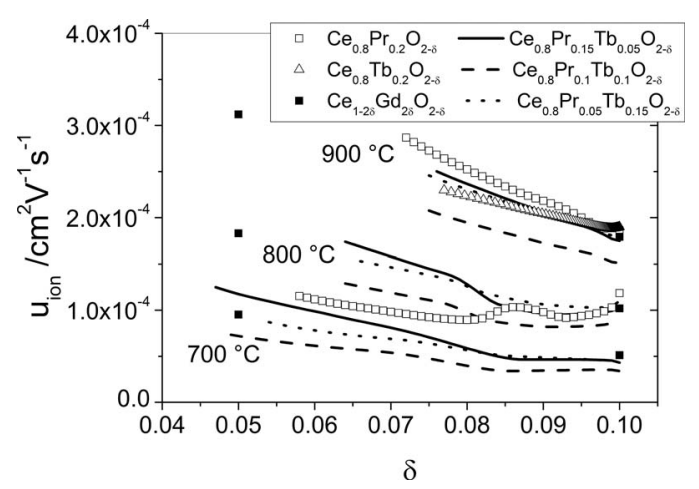

Figure 8. Ionic mobility of $\mathrm{Ce}_{0.8} \mathrm{Pr}_{\mathrm{x}} \mathrm{Tb}_{0.2-\mathrm{x}} \mathrm{O}_{2-\delta}$ as a function of oxygen nonstoichiometry at 700,800 and $900^{\circ} \mathrm{C}$.

defect interaction with increasing concentration of defects. ${ }^{12}$ When comparing the ionic mobility of the various compositions at a certain oxygen nonstoichiometry at $900^{\circ} \mathrm{C}$ it appears that $\mathrm{Ce}_{0.8} \mathrm{Pr}_{0.2} \mathrm{O}_{2-\delta}$ exhibits the highest ionic mobility. The ionic mobility decreases when co-doping with $\mathrm{Tb}$, reaching a minimum for the composition $\mathrm{Ce}_{0.8} \mathrm{Pr}_{0.1} \mathrm{~Tb}_{0.1} \mathrm{O}_{2-\delta}$ and increases again with further $\mathrm{Tb}$ doping, with the compositions $\mathrm{Ce}_{0.8} \mathrm{Pr}_{0.05} \mathrm{~Tb}_{0.15} \mathrm{O}_{2-\delta}$ and $\mathrm{Ce}_{0.8} \mathrm{~Tb}_{0.2} \mathrm{O}_{2-\delta}$ exhibiting a similar ionic mobility as $\mathrm{Ce}_{0.8} \mathrm{Pr}_{0.15} \mathrm{~Tb}_{0.05} \mathrm{O}_{2-\delta}$. The ionic mobility of the $\mathrm{Ce}_{0.8} \mathrm{Pr}_{\mathrm{x}} \mathrm{Tb}_{0.2-\mathrm{x}} \mathrm{O}_{2-\delta}$ compounds is similar to that of $\mathrm{Ce}_{0.9} \mathrm{Gd}_{0.1} \mathrm{O}_{1.95}$ and $\mathrm{Ce}_{0.8} \mathrm{Gd}_{0.2} \mathrm{O}_{1.9}$ at the same oxygen vacancy concentration.

A similar behavior can be observed for the co-doped compositions at lower temperatures from Fig. 8. $\mathrm{Ce}_{0.8} \mathrm{Pr}_{0.1} \mathrm{~Tb}_{0.1} \mathrm{O}_{2-\delta}$ shows the lowest mobility for ionic transport, whereas the remaining two codoped compositions, $\mathrm{Ce}_{0.8} \mathrm{Pr}_{0.05} \mathrm{~Tb}_{0.15} \mathrm{O}_{2-\delta}$ and $\mathrm{Ce}_{0.8} \mathrm{Pr}_{0.15} \mathrm{~Tb}_{0.05} \mathrm{O}_{2-\delta}$, exhibit similar ionic mobilities. Total conductivity measurements were not performed for the singly doped compounds, $\mathrm{Ce}_{0.8} \mathrm{Pr}_{0.2} \mathrm{O}_{2-\delta}$ and $\mathrm{Ce}_{0.8} \mathrm{~Tb}_{0.2} \mathrm{O}_{2-\delta}$, at lower temperatures. The ionic mobility of $\mathrm{Ce}_{0.8} \operatorname{Pr}_{0.2} \mathrm{O}_{2-\delta}$ at $800^{\circ} \mathrm{C}$, shown in Fig. 8, was estimated from data obtained from a symmetrically blocking cell with local ionic and electronic probes, used for the determination of the ionic interference effect. ${ }^{1}$ The estimated ionic mobility of $\mathrm{Ce}_{0.8} \mathrm{Pr}_{0.2} \mathrm{O}_{2-\delta}$ at $800^{\circ} \mathrm{C}$ is lower than that of the co-doped compositions, in contrast to what was found at $900^{\circ} \mathrm{C}$. Although the validity of this finding cannot be excluded, it may also arise due to experimental uncertainty related to the use of a different setup.

Another possible explanation for the inferior ionic mobility of $\mathrm{Ce}_{0.8} \operatorname{Pr}_{0.2} \mathrm{O}_{2-\delta}$ at $800^{\circ} \mathrm{C}$ is the influence of the ionic interference effect. As discussed previously, the quantity $\sigma_{\text {tot }}-\sigma_{\text {el }}^{\prime}$, which is taken here to represent the partial ionic conductivity is only equal to $\sigma_{\text {ion }}$ if there is no interference between the ionic and electronic flows. The cross coefficients of transport for $\mathrm{Ce}_{0.8} \mathrm{Pr}_{0.2} \mathrm{O}_{2-\delta}$ at $800^{\circ} \mathrm{C}$ were found to be far from negligible in the oxygen nonstoichiometry range discussed here and to increase with decreasing oxygen nonstoichiometry. ${ }^{1}$ Neglecting the ionic interference effect, results in an underestimation of the ionic conductivity. This is also causing the ionic mobility of $\mathrm{Ce}_{0.8} \mathrm{Pr}_{0.2} \mathrm{O}_{2-\delta}$ at $800^{\circ} \mathrm{C}$ to appear relatively insensitive with respect to changes in oxygen nonstoichiometry. Since the ionic interference effect increases with decreasing oxygen nonstoichiometry, the ionic conductivity of $\mathrm{Ce}_{0.8} \mathrm{Pr}_{0.2} \mathrm{O}_{2-\delta}$ is underestimated more severely at lower oxygen nonstoichiometries, which causes the observed flattening of the ionic mobility versus oxygen nonstoichiometry. Non-negligible ionic interference may also be the case for the remaining compositions, masking the true behavior of the ionic mobility. In any case, the values presented here can be viewed as a lower boundary for the ionic mobilities of the $\mathrm{Ce}_{0.8} \mathrm{Pr}_{\mathrm{x}} \mathrm{Tb}_{0.2-\mathrm{x}} \mathrm{O}_{2-\delta}$ compounds.

The activation energy and pre-exponential factor of the ionic mobilities of $\mathrm{Ce}_{0.8} \mathrm{Pr}_{\mathrm{x}} \mathrm{Tb}_{0.2-\mathrm{x}} \mathrm{O}_{2-\delta}$ were estimated from linear fitting of the $\ln \left(u_{\text {ion }} T\right)$ versus $1 / T$ data. The mean values, obtained for $\delta$ between $\sim 0.075$ and 0.1 , are given in Table III. A positive correlation is observed between the estimated activation energy and pre-exponential 
Table III. Activation energy and pre-exponential factor of the ionic mobility of $\mathrm{Ce}_{0.8} \operatorname{Pr}_{\mathrm{x}} \mathrm{Tb}_{0.2-\mathrm{x}} \mathrm{O}_{2-\delta}$. Mean values are given for $\delta$ between $\sim 0.075$ and 0.1 , whereas the uncertainty corresponds to the standard deviation from the mean value.

\begin{tabular}{ccc}
$\begin{array}{c}{[\mathrm{Pr}]} \\
=0.20-[\mathrm{Tb}]\end{array}$ & $\begin{array}{c}u_{i o n}^{0} \\
\left(\mathrm{Kcm}^{2} \mathrm{~V}^{-1} \mathrm{~s}^{-1}\right)\end{array}$ & $\begin{array}{c}E_{\mathrm{a}} \\
(\mathrm{eV})\end{array}$ \\
\hline 0.15 & $700 \pm 200$ & $0.80 \pm 0.03$ \\
0.10 & $1200 \pm 400$ & $0.87 \pm 0.03$ \\
0.05 & $610 \pm 90$ & $0.79 \pm 0.02$
\end{tabular}

factor. Such a correlation has already been observed for acceptor doped ceria, when the dopant content is larger than what required in order to obtain a minimum activation energy. ${ }^{3,14}$ As can be seen from Table III, $\mathrm{Ce}_{0.8} \operatorname{Pr}_{0.15} \mathrm{~Tb}_{0.05} \mathrm{O}_{2-\delta}$ and $\mathrm{Ce}_{0.8} \mathrm{Pr}_{0.05} \mathrm{~Tb}_{0.15} \mathrm{O}_{2-\delta}$ have similar activation energy and pre-exponential factor, whereas somewhat larger $E_{\mathrm{a}}$ and $u_{i o n}^{0}$ values were determined for $\mathrm{Ce}_{0.8} \mathrm{Pr}_{0.1} \mathrm{~Tb}_{0.1} \mathrm{O}_{2-\delta}$. A larger activation energy leads to lower ionic mobility, whereas the opposite is expected for the pre-exponential factor. A lower ionic mobility was found for $\mathrm{Ce}_{0.8} \mathrm{Pr}_{0.1} \mathrm{~Tb}_{0.1} \mathrm{O}_{2-\delta}$, as compared to $\mathrm{Ce}_{0.8} \mathrm{Pr}_{0.15} \mathrm{~Tb}_{0.05} \mathrm{O}_{2-\delta}$ and $\mathrm{Ce}_{0.8} \mathrm{Pr}_{0.05} \mathrm{~Tb}_{0.15} \mathrm{O}_{2-\delta}$ that exhibited similar ionic mobilities (see Fig. 8). The activation energy thus seems to be the determining factor for the ionic mobility, in accordance with previous observations. ${ }^{3,14}$ The estimated activation energies are somewhat larger than those calculated by Andersson et al. for ceria doped with $4.2 \%$ Pr or Tb, being in the range $0.7-0.75 \mathrm{eV}{ }^{11}$ The larger activation energies determined here are not surprising, considering the much larger doping level (20\%). Our values lie between the two limiting cases calculated by Andersson et al.; dopant ions being separated from an oxygen vacancy ( $0.69 \mathrm{eV}$ for Pr and $0.66 \mathrm{eV}$ for $\mathrm{Tb}$ ) or being nearest neighbors to one (0.83 eV for Pr and $0.90 \mathrm{eV}$ for Tb), corresponding to dilute solutions and heavy doping, respectively. When the doping level increases, vacancies will experience more trivalent dopants in their immediate neighborhood, on average. This results in a higher migration barrier, as it is less favorable for an oxide ion to move through a saddle point close to large trivalent ions than to move close to smaller $\mathrm{Ce}^{4+}$ ions.

Despite the significant enhancement of the electronic conductivity of $\mathrm{Ce}_{0.8} \mathrm{Pr}_{\mathrm{x}} \mathrm{Tb}_{0.2-\mathrm{x}} \mathrm{O}_{2-\delta}$ relative to $\mathrm{Ce}_{0.9} \mathrm{Gd}_{0.1} \mathrm{O}_{1.95}$ at high oxygen activities (Fig. 3), the charge transport in $\mathrm{Ce}_{0.8} \mathrm{Pr}_{\mathrm{x}} \mathrm{Tb}_{0.2-\mathrm{x}} \mathrm{O}_{2-\delta}$ remains predominantly ionic at temperatures above $700^{\circ} \mathrm{C}$ (Fig. 7). Since the activation energy of the electronic mobility is smaller than that of the ionic (Tables I and III), the relative magnitude of the electronic conductivity is expected to increase with decreasing temperature and eventually dominate. In order to demonstrate this, the oxygen activity dependence of the total and partial conductivities of $\mathrm{Ce}_{0.8} \mathrm{Pr}_{0.1} \mathrm{~Tb}_{0.1} \mathrm{O}_{2-\delta}$ is plotted in Fig. 9 at 800 and $400^{\circ} \mathrm{C}$. At $800^{\circ} \mathrm{CCe}_{0.8} \mathrm{Pr}_{0.1} \mathrm{~Tb}_{0.1} \mathrm{O}_{2-\delta}$ is predominantly ionic conducting, whereas at temperatures below $400^{\circ} \mathrm{C}$ it is predominantly electronic conducting. This shift affects the $\mathrm{a}_{\mathrm{O} 2}$

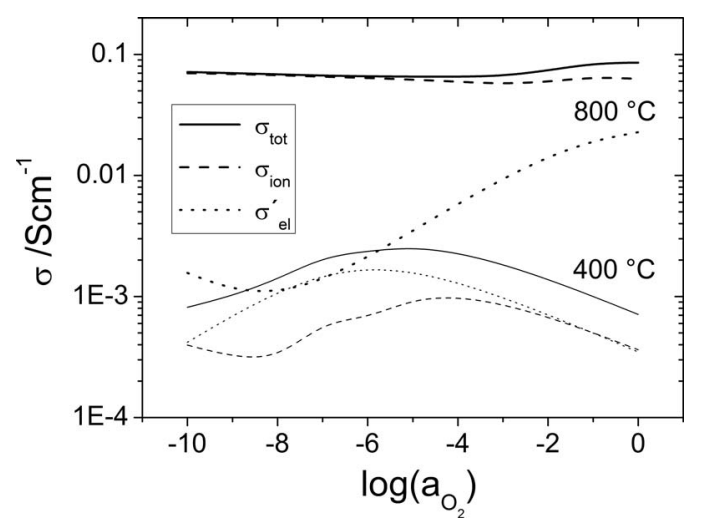

Figure 9. Total $\left(\sigma_{\mathrm{tot}}\right)$ and partial ionic $\left(\sigma_{\mathrm{ion}}\right)$ and electronic $\left(\sigma_{\mathrm{el}}^{\prime}\right)$ conductivities of $\mathrm{Ce}_{0.8} \operatorname{Pr}_{0.1} \mathrm{~Tb}_{0.1} \mathrm{O}_{2-\delta}$ at $800^{\circ} \mathrm{C}$ and $400^{\circ} \mathrm{C}$ as a function of oxygen activity. dependence of the total conductivity from being rather flat at $800^{\circ} \mathrm{C}$ to exhibiting a maximum at $400^{\circ} \mathrm{C}$, following the $\mathrm{a}_{\mathrm{O} 2}$ dependence of the electronic conductivity. The partial conductivities at $400^{\circ} \mathrm{C}$ were calculated on the basis of the defect chemistry of $\mathrm{Ce}_{0.8} \operatorname{Pr}_{0.1} \mathrm{~Tb}_{0.1} \mathrm{O}_{2-\delta}{ }^{38}$ the electronic mobility values (Table I), and a linear extrapolation of the oxygen nonstoichiometry dependence of the ionic mobility (Fig. 8) at smaller $\delta$ values and temperatures (on the basis of an Arrhenius expression).

Oxygen permeation. - In the previous, the electronic and ionic transport properties of $\mathrm{Ce}_{0.8} \mathrm{Pr}_{\mathrm{x}} \mathrm{Tb}_{0.2-\mathrm{x}} \mathrm{O}_{2-\delta}$ were presented and discussed. A significant enhancement of the electronic conductivity at high oxygen activities ( $\operatorname{loga}_{\mathrm{O} 2} \sim-10$ or higher) was observed relative to that of other rare earth doped ceria systems, such as $\mathrm{Ce}_{0.9} \mathrm{Gd}_{0.1} \mathrm{O}_{1.95}$ (Fig. 3). At the same time, the $\mathrm{Ce}_{0.8} \mathrm{Pr}_{\mathrm{x}} \mathrm{Tb}_{0.2-\mathrm{x}} \mathrm{O}_{2-\delta}$ compounds were found to have ionic mobilities similar to that of $\mathrm{Ce}_{0.9} \mathrm{Gd}_{0.1} \mathrm{O}_{1.95}$ (Fig. 8), which is considered as one of the best ionic conducting cerates. ${ }^{12}$ On the basis of these results, the $\mathrm{Ce}_{0.8} \mathrm{Pr}_{\mathrm{x}} \mathrm{Tb}_{0.2-\mathrm{x}} \mathrm{O}_{2-\delta}$ compounds appear as promising candidates for oxygen separation membranes, particularly for high $\mathrm{a}_{\mathrm{O} 2}$ processes, such as oxyfuel processes. ${ }^{53}$ In the following, the performance of a $30 \mu \mathrm{m}$ thick $\mathrm{Ce}_{0.8} \operatorname{Pr}_{\mathrm{x}} \mathrm{Tb}_{0.2-\mathrm{x}} \mathrm{O}_{2-\delta}$ membrane is evaluated.

As discussed previously, if the cross coefficients of transport are not negligible, the ionic conductivity of the $\mathrm{Ce}_{0.8} \mathrm{Pr}_{\mathrm{x}} \mathrm{Tb}_{0.2-\mathrm{x}} \mathrm{O}_{2-\delta}$ compounds is underestimated, due to the false assumption of negligible ionic interference. This will in turn result in an underestimation of the oxygen flux. A further underestimation of the oxygen flux will arise directly from the negligence of the ionic interference effect. We were obliged to assume negligible ionic interference in the previous, since the interference effect is not known for the $\mathrm{Ce}_{0.8} \mathrm{Pr}_{\mathrm{x}} \mathrm{Tb}_{0.2-\mathrm{x}} \mathrm{O}_{2-\delta}$ compounds, apart from the case of $\mathrm{Ce}_{0.8} \mathrm{Pr}_{0.2} \mathrm{O}_{2-\delta}$ at $800^{\circ} \mathrm{C}$. The ionic interference effect of $\mathrm{Ce}_{0.8} \mathrm{Pr}_{0.2} \mathrm{O}_{2-\delta}$, measured as a function of the oxygen activity at $800^{\circ} \mathrm{C}$, was found to be negligible for loga $\mathrm{O}_{2}<-4$, but far from zero at higher oxygen activities. ${ }^{1}$

The error induced in the determination of the oxygen flux from the assumption of negligible ionic interference, in the event that this assumption is false, is estimated for the case of $\mathrm{Ce}_{0.8} \mathrm{Pr}_{0.2} \mathrm{O}_{2-\delta}$ at $800^{\circ} \mathrm{C}$. For this, the oxygen flux of a $30 \mu \mathrm{m}$ thick $\mathrm{Ce}_{0.8} \operatorname{Pr}_{0.2} \mathrm{O}_{2-\delta}$ membrane has been estimated at $800^{\circ} \mathrm{C}$ using the $\mathrm{a}_{\mathrm{O} 2}$ dependence of all the Onsager coefficients of transport, including the cross terms. ${ }^{1}$ This is shown in Fig. 10 as a function of the oxygen activity of the anode gas (using air at the cathode side) and is labeled "with interference". The "zero interference" curve corresponds to the case where the knowledge of the ionic interference effect is used to correctly estimate the partial conductivities of $\mathrm{Ce}_{0.8} \mathrm{Pr}_{0.2} \mathrm{O}_{2-\delta}$ as a function of $\mathrm{a}_{\mathrm{O} 2}$, but the cross terms of the Onsager matrix of transport are then set to zero for the estimation of the oxygen flux. Finally, the "neglected interference" case includes both the error due to the underestimation of the partial

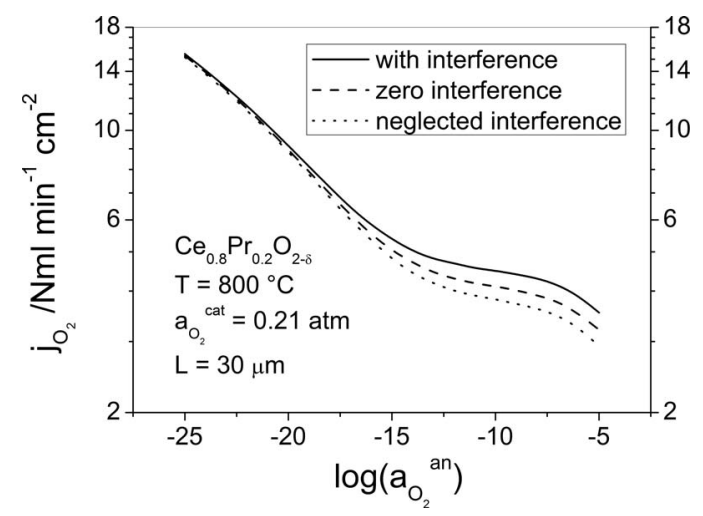

Figure 10. Influence of the ionic interference effect on the oxygen flux delivered by a $30 \mu \mathrm{m}$ thick $\mathrm{Ce}_{0.8} \mathrm{Pr}_{0.2} \mathrm{O}_{2-\delta}$ membrane as a function of the anode oxygen activity at $800^{\circ} \mathrm{C}$. $\mathrm{a}_{\mathrm{O} 2}{ }^{\text {cat }}=0.21$. 


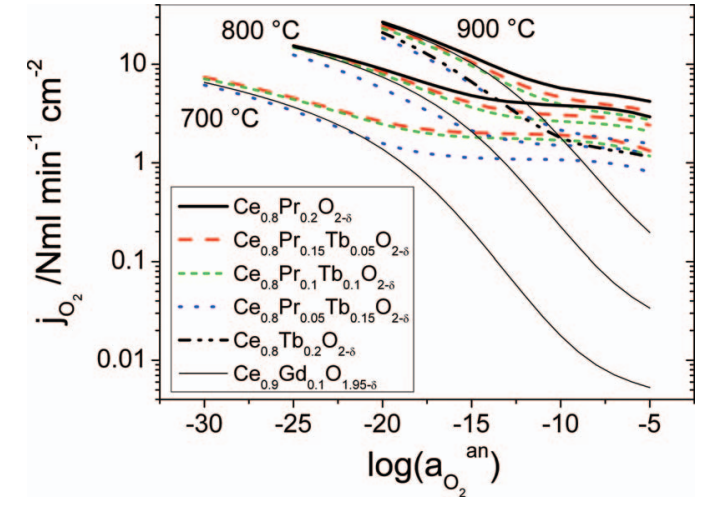

Figure 11. Estimated oxygen flux delivered by a $30 \mu \mathrm{m}$ thick $\mathrm{Ce}_{0.8} \mathrm{Pr}_{\mathrm{x}} \mathrm{Tb}_{0.2-\mathrm{x}} \mathrm{O}_{2-\delta}$ or $\mathrm{Ce}_{0.9} \mathrm{Gd}_{0.1} \mathrm{O}_{1.95-\delta}$ membrane operating at 700,800 or $900^{\circ} \mathrm{C}$ as a function of the oxygen activity of the anode gas. $\mathrm{a}_{\mathrm{O} 2}{ }^{\mathrm{cat}}=0.21$.

ionic conductivity and the error due to the negligence of the ionic interference effect in the estimation of the oxygen flux.

As can be seen from Fig. 10, the presence of ionic interference has a positive effect on the oxygen flux. For the particular case of a $30 \mu \mathrm{m}$ thick $\mathrm{Ce}_{0.8} \operatorname{Pr}_{0.2} \mathrm{O}_{2-\delta}$ membrane operating at $800^{\circ} \mathrm{C}$, with air at one side and an oxygen activity of $10^{-5}$ at the other, including the ionic interference effect results in a $20 \%$ larger oxygen flux relative to the case where the ionic interference is assumed negligible. The difference in oxygen flux between the "with interference" and the "zero interference" case corresponds to the direct influence of the ionic interference effect on the deliverable oxygen flux. The sharp increase of the oxygen flux for oxygen activities of the anode gas below ca. $10^{-13}$ is associated with the reduction of Ce that takes place under such reducing conditions, enhancing the electronic conductivity of the membrane and thereby the oxygen flux that it can deliver.

A comparison between the oxygen flux that can be delivered by a $30 \mu \mathrm{m}$ thick $\mathrm{Ce}_{0.8} \mathrm{Pr}_{\mathrm{x}} \mathrm{Tb}_{0.2-\mathrm{x}} \mathrm{O}_{2-\delta}$ or $\mathrm{Ce}_{0.9} \mathrm{Gd}_{0.1} \mathrm{O}_{1.95-\delta}$ membrane operating at 700,800 or $900^{\circ} \mathrm{C}$ as a function of the oxygen activity of the anode gas is presented in Fig. 11. The ionic interference effect was assumed negligible and a cathode oxygen activity of 0.21 was used in all cases. As can be seen, all $\mathrm{Ce}_{0.8} \mathrm{Pr}_{\mathrm{x}} \mathrm{Tb}_{0.2-\mathrm{x}} \mathrm{O}_{2-\delta}$ compositions yield a significantly larger oxygen flux than $\mathrm{Ce}_{0.9} \mathrm{Gd}_{0.1} \mathrm{O}_{1.95-\delta}$ at high oxygen activities of the anode gas. This is due to the enhanced electronic conductivity of $\mathrm{Ce}_{0.8} \mathrm{Pr}_{\mathrm{x}} \mathrm{Tb}_{0.2-\mathrm{x}} \mathrm{O}_{2-\delta}$ compounds at high oxygen activities, as compared to $\mathrm{Ce}_{0.9} \mathrm{Gd}_{0.1} \mathrm{O}_{1.95-\delta}$.

The enhancement of the oxygen flux increases with increasing $\mathrm{Pr} / \mathrm{Tb}$ ratio. This is due to the increasing electronic conductivity with increasing $\mathrm{Pr} / \mathrm{Tb}$ ratio, shown in Fig. 4a-4c. Larger oxygen fluxes are predicted for composition $\mathrm{Ce}_{0.8} \operatorname{Pr}_{0.1} \mathrm{~Tb}_{0.1} \mathrm{O}_{2-\delta}$ relative to $\mathrm{Ce}_{0.8} \mathrm{Pr}_{0.05} \mathrm{~Tb}_{0.15} \mathrm{O}_{2-\delta}$ despite the fact that $\mathrm{Ce}_{0.8} \mathrm{Pr}_{0.1} \mathrm{~Tb}_{0.1} \mathrm{O}_{2-\delta}$ was found to have the lowest ionic mobility among the examined compositions. This is again pointing out the importance of the electronic conductivity in terms of enhancing the oxygen flux.

As the oxygen activity of the anode gas decreases, the flux that can be delivered by a $\mathrm{Ce}_{0.9} \mathrm{Gd}_{0.1} \mathrm{O}_{1.95-\delta}$ membrane approaches that of $\mathrm{a} \mathrm{Ce}_{0.8} \mathrm{Pr}_{\mathrm{x}} \mathrm{Tb}_{0.2-\mathrm{x}} \mathrm{O}_{2-\delta}$ membrane. This is due to the increasing contribution of small polarons in the $\mathrm{Ce} 4 \mathrm{f}$ band to the electronic conductivity, which overshadows the influence of the increased electronic conductivity of the $\mathrm{Ce}_{0.8} \mathrm{Pr}_{\mathrm{x}} \mathrm{Tb}_{0.2-\mathrm{x}} \mathrm{O}_{2-\delta}$ compounds at high $\mathrm{a}_{\mathrm{O} 2}$.

Fagg et al. ${ }^{31}$ have measured the oxygen flux delivered by a $1 \mathrm{~mm}$ thick $\mathrm{Ce}_{0.8} \mathrm{Pr}_{0.2} \mathrm{O}_{2-\delta}$ membrane operating between $\mathrm{a}_{\mathrm{O} 2}{ }^{\text {an }}=0.021$ and $\mathrm{a}_{\mathrm{O} 2}{ }^{\text {cat }}=0.21$. They reported values of $0.011 \mathrm{Nml} \mathrm{min}^{-1} \mathrm{~cm}^{-2}$ to $0.068 \mathrm{Nml} \mathrm{min} \mathrm{m}^{-1} \mathrm{~cm}^{-2}$ at temperatures between $800^{\circ} \mathrm{C}$ and $1000^{\circ} \mathrm{C}$. Based on the transport properties of $\mathrm{Ce}_{0.8} \mathrm{Pr}_{0.2} \mathrm{O}_{2-\delta}$ presented in this

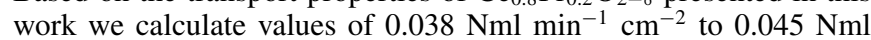
$\min ^{-1} \mathrm{~cm}^{-2}$. These are in reasonable agreement with the experimental results of Fagg et al., considering the uncertainty in electrode performance.

The oxygen activity and oxygen nonstoichiometry profiles, established in a $30 \mu \mathrm{m}$ thick $\mathrm{Ce}_{0.8} \mathrm{Pr}_{0.2} \mathrm{O}_{2-\delta}$ or $\mathrm{Ce}_{0.9} \mathrm{Gd}_{0.1} \mathrm{O}_{1.95-\delta}$ membrane operating at $800^{\circ} \mathrm{C}$ between $\mathrm{a}_{\mathrm{O} 2}{ }^{\text {an }}=10^{-25}$ and $\mathrm{a}_{\mathrm{O} 2}{ }^{\text {cat }}=0.21$, are com-

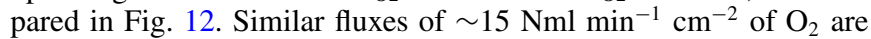
delivered by the two compositions under these conditions (Fig. 11). Nevertheless, the established profiles are significantly different close to the cathode side of the membrane. The oxygen activity decreases abruptly close to the cathode side for $\mathrm{Ce}_{0.9} \mathrm{Gd}_{0.1} \mathrm{O}_{1.95-\delta}$. This is due to the low electronic conductivity of $\mathrm{Ce}_{0.9} \mathrm{Gd}_{0.1} \mathrm{O}_{1.95-\delta}$ within this oxygen activity range. Combining the condition of local ionization equilibrium $\left(\frac{1}{2} O_{2}(g)+V_{O}^{\bullet \bullet}+2 e^{\prime} \leftrightarrow O_{O}^{x}\right)$ with the fact that $\Delta \mu_{V_{O}} \approx 0, \Delta \mu_{O_{O}^{x}} \approx 0$ in $\mathrm{Ce}_{0.9} \mathrm{Gd}_{0.1} \mathrm{O}_{1.95-\delta}$ at high oxygen activities (since $\Delta \delta \approx 0$ ), one can conclude that under these conditions $\Delta \mu_{e} \approx-\frac{R T}{4} \Delta \ln \mathrm{a}_{O_{2}}$. Therefore the abrupt decrease in oxygen activity increases the driving force for electronic transport. This increase compensates for the low electronic conductivity of $\mathrm{Ce}_{0.9} \mathrm{Gd}_{0.1} \mathrm{O}_{1.95-\delta}$ at high oxygen activities, thereby allowing for the large electronic

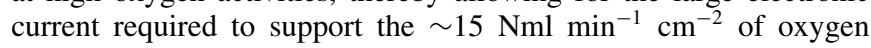
flux. As the oxygen activity decreases, the electronic conductivity of $\mathrm{Ce}_{0.9} \mathrm{Gd}_{0.1} \mathrm{O}_{1.95-\delta}$ increases, the required driving force for electronic transport decreases (since the electronic current that passes through each slab of the membrane is the same), and therefore the slope of the oxygen activity profile decreases.

Due to the increased electronic conductivity of $\mathrm{Ce}_{0.8} \mathrm{Pr}_{0.2} \mathrm{O}_{2-\delta}$ at high oxygen activities, the oxygen activity gradient close to the cathode side is significantly smaller than in $\mathrm{Ce}_{0.9} \mathrm{Gd}_{0.1} \mathrm{O}_{1.95-\delta}$. An abrupt decrease is observed again within the $\mathrm{a}_{\mathrm{O} 2}$ range from $10^{-5}$ to $10^{-12}$, where the electronic conductivity of $\mathrm{Ce}_{0.8} \mathrm{Pr}_{0.2} \mathrm{O}_{2-\delta}$ passes through its minimum, as can be seen from Fig. $4 \mathrm{~b}$. It is clear that the different oxygen activity profiles established in $\mathrm{Ce}_{0.8} \mathrm{Pr}_{0.2} \mathrm{O}_{2-\delta}$ and $\mathrm{Ce}_{0.9} \mathrm{Gd}_{0.1} \mathrm{O}_{1.95-\delta}$ are due to the different electronic conductivities of the two compounds, which in turn arise from their different defect chemistries. The oxygen nonstoichiometry profiles that correspond to the established oxygen activity profiles are also shown in Fig. 12. The overall change in oxygen nonstoichiometry of $\mathrm{Ce}_{0.8} \mathrm{Pr}_{0.2} \mathrm{O}_{2-\delta}$ is larger than that of $\mathrm{Ce}_{0.9} \mathrm{Gd}_{0.1} \mathrm{O}_{1.95-\delta}$, due to reduction of Pr from $\mathrm{Pr}^{4+}$ to $\operatorname{Pr}^{3+}$ with subsequent loss of oxygen at high oxygen activities. This will result in a larger strain across the $\mathrm{Ce}_{0.8} \mathrm{Pr}_{0.2} \mathrm{O}_{2-\delta}$ membrane due to chemical expansion. ${ }^{38}$ It can therefore be concluded that $\mathrm{Ce}_{0.9} \mathrm{Gd}_{0.1} \mathrm{O}_{1.95-\delta}$ is a better choice of a membrane material, when operating the membrane at such a low oxygen activity of the anode gas, since both materials are able to deliver the same oxygen flux while at the same time $\mathrm{Ce}_{0.9} \mathrm{Gd}_{0.1} \mathrm{O}_{1.95-\delta}$ is less prone to mechanical failure due to smaller chemical expansion.

$\mathrm{Ce}_{0.8} \mathrm{Pr}_{0.2} \mathrm{O}_{2-\delta}$ should be preferred though when operating the membrane at high oxygen activities, since it can significantly enhance the oxygen flux compared to $\mathrm{Ce}_{0.9} \mathrm{Gd}_{0.1} \mathrm{O}_{1.95-\delta}$, as shown in Fig. 11 . A high oxygen activity application for oxygen separation membranes that appears very interesting is for use in conjunction with an oxyfuel combustion process, ${ }^{53}$ which is being considered as one among several routes to reduce the cost of carbon capture and sequestration.

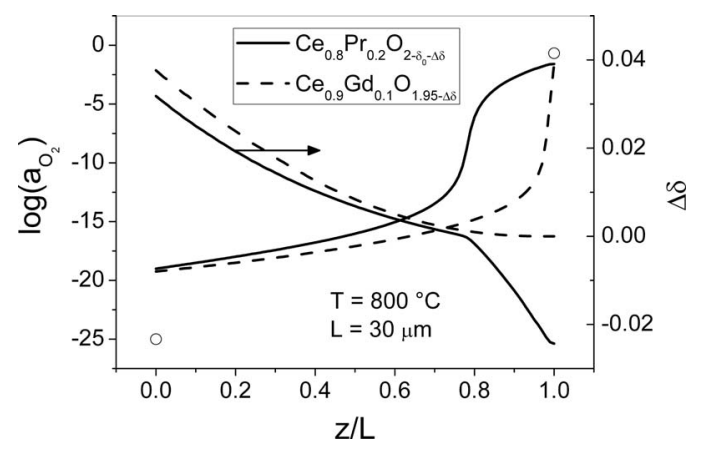

Figure 12. Comparison of the oxygen activity and oxygen nonstoichiometry profiles established in a $30 \mu \mathrm{m}$ thick $\mathrm{Ce}_{0.8} \mathrm{Pr}_{0.2} \mathrm{O}_{2-\delta}$ and $\mathrm{Ce}_{0.9} \mathrm{Gd}_{0.1} \mathrm{O}_{1.95-\delta}$ membrane operating at $800^{\circ} \mathrm{C}$ between $\mathrm{a}_{\mathrm{O} 2}{ }^{\text {an }}=10^{-25}$ and $\mathrm{a}_{\mathrm{O} 2}{ }^{\mathrm{cat}}=0.21$. The open circles correspond to the oxygen activity prevailing at the gas phase. $\delta_{0}=0.1$. 


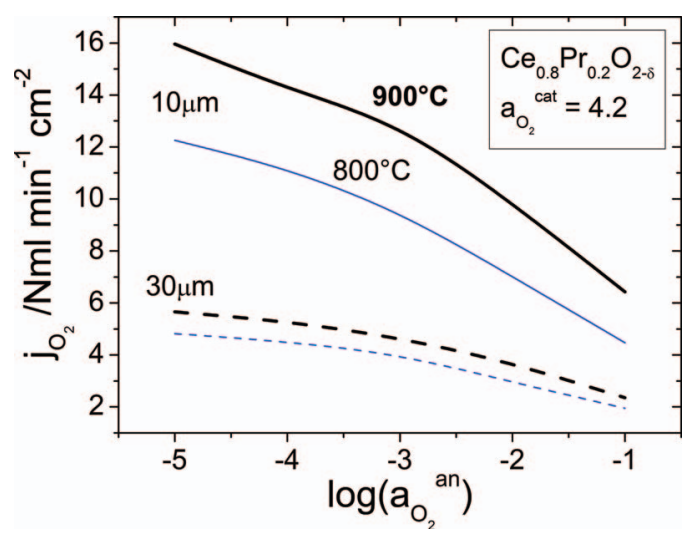

Figure 13. Estimated oxygen flux for a $10 \mu \mathrm{m}$ or $30 \mu \mathrm{m}$ thick $\mathrm{Ce}_{0.8} \operatorname{Pr}_{0.2} \mathrm{O}_{2-\delta}$ membrane at 800 and $900^{\circ} \mathrm{C}$ under oxyfuel operating conditions as a function of the oxygen activity of the anode gas. $\mathrm{a}_{02}{ }^{\text {cat }}=4.2$.

In this application, the oxygen membrane is expected to operate with air compressed at $\sim 20 \mathrm{~atm}$ at the feed side and an oxygen activity of $10^{-5}-10^{-1}$ at the permeate side, depending on the process scheme. An estimate of the oxygen flux for a $\mathrm{Ce}_{0.8} \mathrm{Pr}_{0.2} \mathrm{O}_{2-\delta}$ membrane operating under oxyfuel conditions is shown in Fig. 13 as a function of the oxygen activity of the permeate gas. A polarization resistance of $3.66 \mathrm{mOhm} \mathrm{cm}{ }^{2}$ at $900^{\circ} \mathrm{C}$ and $11.1 \mathrm{mOhm} \mathrm{cm}^{2}$ at $800^{\circ} \mathrm{C}$ was assumed for both electrodes in this case, according to the expression for $R_{\text {cat }}$ given in Ref. 47. A $10 \mu \mathrm{m}$ thick $\mathrm{Ce}_{0.8} \mathrm{Pr}_{0.2} \mathrm{O}_{2-\delta}$ membrane operating at $900^{\circ} \mathrm{C}$ under these conditions would be able to deliver more

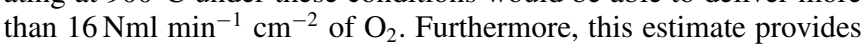
a lower boundary for the expected oxygen flux, as the calculation is based on the assumption of negligible ionic interference, which was shown in Fig. 10 to result in an underestimation of the oxygen flux.

\section{Conclusions}

The electronic and ionic transport properties of $\mathrm{Ce}_{0.8} \operatorname{Pr}_{\mathrm{x}} \mathrm{Tb}_{0.2-\mathrm{x}} \mathrm{O}_{2-\delta}(\mathrm{x}=0,0.05,0.10,0.15,0.20)$ were determined as a function of the oxygen activity in the range from $\mathrm{a}_{\mathrm{O} 2}$ $\approx 10^{3}$ to $\mathrm{a}_{\mathrm{O} 2} \approx 10^{-17}$ at temperatures between $700^{\circ} \mathrm{C}$ and $900^{\circ} \mathrm{C}$. The electronic conductivity of $\mathrm{Ce}_{0.8} \mathrm{Pr}_{\mathrm{x}} \mathrm{Tb}_{0.2-\mathrm{x}} \mathrm{O}_{2-\delta}$ under suppressed ionic flow, determined by Hebb-Wagner polarization, was found to be significantly enhanced relative to that of $\mathrm{Ce}_{0.9} \mathrm{Gd}_{0.1} \mathrm{O}_{1.95-\delta}$ in the high $\mathrm{a}_{\mathrm{O} 2}$ range $\left(\mathrm{a}_{\mathrm{O} 2}>10^{-8}\right)$, by as much as three orders of magnitude. Furthermore, the electronic conductivity was found to increase systematically with increasing $\mathrm{Pr} / \mathrm{Tb}$ ratio in the $\mathrm{a}_{\mathrm{O} 2}$ regime dominated by small polaron hopping at the $\mathrm{Pr} / \mathrm{Tb} 4 \mathrm{f}$ band.

The ionic conductivity was estimated by subtracting the electronic conductivity, measured under suppressed ionic flow, from the total conductivity. This methodology results in an underestimation of the ionic conductivity in the event of non-negligible ionic interference between ionic and electronic flows. In that case, the obtained values represent a lower boundary of the ionic mobilities of the $\mathrm{Ce}_{0.8} \mathrm{Pr}_{\mathrm{x}} \mathrm{Tb}_{0.2-\mathrm{x}} \mathrm{O}_{2-\delta}$ compounds. $\mathrm{Ce}_{0.8} \mathrm{Pr}_{0.2} \mathrm{O}_{2-\delta}$ was found to exhibit the highest ionic mobility among the $\mathrm{Ce}_{0.8} \mathrm{Pr}_{\mathrm{x}} \mathrm{Tb}_{0.2-\mathrm{x}} \mathrm{O}_{2-\delta}$ compounds at $900^{\circ} \mathrm{C}$. The ionic mobility was found to decrease when co-doping with $\mathrm{Tb}$, reaching a minimum for the composition $\mathrm{Ce}_{0.8} \mathrm{Pr}_{0.1} \mathrm{~Tb}_{0.1} \mathrm{O}_{2-\delta}$ and to increase again with further $\mathrm{Tb}$ doping. A similar behavior was observed for the co-doped compositions at lower temperatures. The ionic mobility of $\mathrm{Ce}_{0.8} \mathrm{Pr}_{\mathrm{x}} \mathrm{Tb}_{0.2-\mathrm{x}} \mathrm{O}_{2-\delta}$ is similar to that of $\mathrm{Ce}_{0.9} \mathrm{Gd}_{0.1} \mathrm{O}_{1.95}$ and $\mathrm{Ce}_{0.8} \mathrm{Gd}_{0.2} \mathrm{O}_{1.9}$ at the same oxygen vacancy concentration. Increased microstrain may be a possible explanation for the decreased ionic mobility of compositions $\mathrm{Ce}_{0.8} \mathrm{Pr}_{0.1} \mathrm{~Tb}_{0.1} \mathrm{O}_{1.95}$ and $\mathrm{Ce}_{0.8} \operatorname{Pr}_{0.05} \mathrm{~Tb}_{0.15} \mathrm{O}_{1.95}$. The ionic mobility was observed to decrease with increasing oxygen nonstoichiometry for all compositions.

The oxygen flux that can be delivered by a $30 \mu \mathrm{m}$ thick $\mathrm{Ce}_{0.8} \mathrm{Pr}_{\mathrm{x}} \mathrm{Tb}_{0.2-\mathrm{x}} \mathrm{O}_{2-\delta}$ membrane was estimated to be significantly larger than that of a $\mathrm{Ce}_{0.9} \mathrm{Gd}_{0.1} \mathrm{O}_{1.95-\delta}$ membrane at high oxygen activities of the permeate side $\left(\mathrm{a}_{\mathrm{O} 2}{ }^{\text {an }}>10^{-15}\right)$, due to the enhanced electronic conductivity of $\mathrm{Ce}_{0.8} \mathrm{Pr}_{\mathrm{x}} \mathrm{Tb}_{0.2-\mathrm{x}} \mathrm{O}_{2-\delta}$. The enhancement of the oxygen flux was found to increase with increasing $\mathrm{Pr} / \mathrm{Tb}$ ratio, due to the increasing electronic conductivity with increasing $\mathrm{Pr} / \mathrm{Tb}$. A $10 \mu \mathrm{m}$ thick $\mathrm{Ce}_{0.8} \operatorname{Pr}_{0.2} \mathrm{O}_{2-\delta}$ membrane, operating at $900^{\circ} \mathrm{C}$ with air compressed at $\sim 20$ atm at one side and an oxygen activity of $\sim 10^{-5}$ at the other side (oxyfuel operating conditions), would be able to deliver more than $16 \mathrm{Nml} \mathrm{min} \mathrm{mm}^{-1} \mathrm{~cm}^{-2}$ of $\mathrm{O}_{2}$. On the other hand, $\mathrm{Ce}_{0.9} \mathrm{Gd}_{0.1} \mathrm{O}_{1.95-\delta}$ was concluded to be a better choice of a membrane material when operating the membrane at low oxygen activities of the anode gas $\left(\mathrm{a}_{\mathrm{O} 2}{ }^{\text {an }}<10^{-20}\right)$, since it is able to deliver the same oxygen flux as $\mathrm{Ce}_{0.8} \mathrm{Pr}_{0.2} \mathrm{O}_{2-\delta}$, while exhibiting smaller chemical expansion. Finally, the influence of non-negligible ionic interference on the deliverable oxygen flux was investigated for the case of $\mathrm{Ce}_{0.8} \mathrm{Pr}_{0.2} \mathrm{O}_{2-\delta}$. The presence of ionic interference was found to have a large and positive effect on the oxygen flux.

\section{Acknowledgments}

Financial support from the Danish Council for Strategic Research and the Danish Natural Science Research Council is gratefully acknowledged.

\section{References}

1. C. Chatzichristodoulou, W. S. Park, H. S. Kim, P. V. Hendriksen, and H. I. Yoo, Phys. Chem. Chem. Phys., 12, 9637 (2010).

2. V. V. Kharton, F. M. Figueiredo, L. Navarro, E. N. Naumovich, A. V. Kovalevsky, A. A. Yaremchenko, A. P. Viskup, A. Carneiro, F. M. B. Marques, and J. R. Frade, J. Mater. Sci., 36, 1105 (2001).

3. J. Faber, C. Geoffroy, A. Roux, A. Sylvestre, and P. Abélard, Appl. Phys. A, 49, 225 (1989).

4. D. K. Hohnke, Solid State Ionics, 5, 531 (1981).

5. M. Mogensen, T. Lindegaard, and U. R. Hansen, J. Electrochem. Soc., 141, 2122 (1994).

6. D. Y. Wang, D. S. Park, J. Griffith, and A. S. Nowick, Solid State Ionics, 2, 95 (1981).

7. H. Inaba and H. Tagawa, Solid State Ionics, 83, 1 (1996).

8. J. A. Kilner and B. C. H. Steele, in Non-stoichiometric Oxides, O. T. Sørensen, Editor, p. 233, Academic Press, New York (1981).

9. V. Butler, C. R. A. Catlow, B. E. F. Fender, and J. H. Harding, Solid State Ionics, 8, 109 (1983).

10. L. Minervini, M. O. Zacate, and R. W. Grimes, Solid State Ionics, 116, 339 (1999).

11. D. A. Andersson, S. I. Simak, N. V. Skorodumova, I. A. Abrikosov, and B. Johansson, Proc. Natl. Acad. Sci. U.S.A., 103, 3518 (2006).

12. B. C. H. Steele, Solid State Ionics, 129, 95 (2000).

13. H. Yahiro, K. Eguchi, and H. Arai, Solid State Ionics, 36, 71 (1989).

14. S. Omar, E. D. Wachsman, J. L. Jones, and J. C. Nino, J. Am. Ceram. Soc., 92, 2674 (2009).

15. X. Sha, Z. Lü, X. Huang, J. Miao, L. Jia, X. Xin, and W. Su, J. Alloy Compd., 424, 315 (2006)

16. F. Y. Wang, S. Y. Chen, W. Qin, S. X. Yu, and S. F. Cheng, Catal. Today, 97, 189 (2004).

17. F. Wang, S. Chen, and S. Cheng, Electrochem. Commun., 6, 743 (2004).

18. T. Mori, J. Drennan, J. Lee, J. Li, and T. Ikegami, Solid State Ionics, 154-155, 461 (2002).

19. H. L. Tuller and A. S. Nowick, J. Phys. Chem. Sol., 38, 859 (1977).

20. B. Dalslet, P. Blennow, P. Hendriksen, N. Bonanos, D. Lybye, and M. Mogensen, J. Solid State Electr. 10, 547 (2006).

21. C. Chatzichristodoulou, M. Søgaard, J. Glasscock, A. Kaiser, S. P. V. Foghmoes, and P. V. Hendriksen, J. Electrochem. Soc, 158, F73 (2011).

22. Y. Takasu, T. Sugino, and Y. Matsuda, J. Appl. Electrochem., 14, 79 (1984).

23. M. Nauer, C. Ftikos, and B. C. H. Steele, J. Eur. Ceram. Soc., 14, 493 (1994).

24. W. Huang, P. Shuk, and M. Greenblatt, Solid State Ionics, 113, 305 (1998).

25. P. Shuk and M. Greenblatt, Solid State Ionics, 116, 217 (1999).

26. P. Shuk, M. Greenblatt, and M. Croft, Chem. Mater, 11, 473 (1999).

27. S. Lübke and H. Wiemhöfer, Solid State Ionics, 117, 229 (1999).

28. T. Stefanik and H. Tuller, Solid State Ionics, 756, 163 (2003).

29. X. Qi, Y. Lin, C. Holt, and S. Swartz, J. Mater. Sci., 38, 1073 (2003).

30. D. P. Fagg, V. V. Kharton, A. Shaula, I. P. Marozau, and J. R. Frade, Solid State Ionics, 176, 1723 (2005).

31. D. P. Fagg, I. P. Marozau, A. L. Shaula, V. V. Kharton, and J. R. Frade, J. Solid State Chem., 179, 3347 (2006)

32. D. P. Fagg, S. García-Martin, V. V. Kharton, and J. R. Frade, Chem. Mater, 21, 381 (2009).

33. S. R. Bishop, T. S. Stefanik, and H. L. Tuller, Phys. Chem. Chem. Phys., 13, 10165 (2011).

34. K. Schmale, M. Grünebaum, M. Janssen, S. Baumann, F. Schulze-Küppers, and H. Wiemhöfer, Phys. Stat. Sol. B, 248, 314 (2011). 
35. M. Balaguer, C. Solis, and J. M. Serra, Chem. Mater., 23, 2333 (2011)

36. C. Chatzichristodoulou, P. V. Hendriksen, A. Hagen, and J. Grivel, ECS Trans., 13 347 (2008).

37. C. Chatzichristodoulou and P. V. Hendriksen, J. Electrochem. Soc., 157, B481 (2010).

38. C. Chatzichristodoulou, P. V. Hendriksen, and A. Hagen, J. Electrochem. Soc., 157, B299 (2010).

39. H.-I. Yoo, J.-H. Lee, M. Martin, J. Janek, and H. Schmalzried, Solid State Ionics, 67, 317 (1994).

40. C. Chatzichristodoulou and P. V. Hendriksen, Phys. Chem. Chem. Phys., 13, 21558 (2011).

41. K. Yashiro, S. Onuma, A. Kaimai, Y. Nigara, T. Kawada, J. Mizusaki, K. Kawamura, T. Horita, and H. Yokokawa, Solid State Ionics, 152-153, 469 (2002).

42. M. H. Hebb, J. Chem. Phys., 20, 185 (1952).
43. C. Wagner, Z Elektrochem, 60, 4 (1956).

44. X. Guo and J. Maier, Solid State Ionics, 130, 267 (2000)

45. C. Wagner and W. Schottky, Z. Phys. Chem. B, 11, 11 (1930).

46. H. Chang and G. Jaffe, J. Chem. Phys., 20, 1071 (1952).

47. C. Chatzichristodoulou, M. Søgaard, and P. V. Hendriksen, J. Electrochem. Soc., 158, F61 (2011).

48. Y. Xiong, K. Yamaji, T. Horita, N. Sakai, and H. Yokokawa, J. Electrochem. Soc., 151, A407 (2004)

49. I. K. Naik and T. Y. Tien, J. Phys. Chem. Solids, 39, 311 (1978).

50. S. H. Park and H. I. Yoo, Phys. Chem. Chem. Phys., 11, 391 (2009).

51. S. Wang, T. Kobayashi, M. Dokiya, and T. Hashimoto, J. Electrochem. Soc., 147, 3606 (2000).

52. Z. Tianshu, P. Hing, H. Huang, and J. Kilner, Solid State Ionics, 148, 567 (2002)

53. X. Tan, K. Li, A. Thursfield, and I. S. Metcalfe, Catal. Today, 131, 292 (2008). 